\title{
From magma ascent to ash generation: investigating volcanic conduit processes by integrating experiments, numerical modeling, and observations
}

Margherita Polacci ${ }^{1}$, Mattia de' Michieli Vitturi ${ }^{2}$, Fabio Arzilli ${ }^{1}$, Michael Richard Burton ${ }^{1}$, Luca Caricchi ${ }^{3}$, Brett Carr ${ }^{4}$, Matteo Cerminara ${ }^{2}$, Corrado Cimarelli ${ }^{5}$, Amanda B. Clarke ${ }^{4}$, Simone Colucci ${ }^{2}$, Antonio Costa ${ }^{6}$, Wim Degruyter ${ }^{7}$, Tim Druitt ${ }^{8}$, Samantha Engwell ${ }^{9}$, Tomaso Esposti Ongaro $^{2}$, Daniele Giordano ${ }^{10}$, Lucia Gurioli ${ }^{8}$, Baptiste Haddadi $^{8}$, Jackie Evan Kendrick ${ }^{11}$, Ulrich Kueppers ${ }^{5}$, Anthony Lamur ${ }^{11}$, Yan Lavallée ${ }^{11}$, Edward Llewellin ${ }^{12}$, Heidy Marita Mader ${ }^{13}$, Nicole Metrich ${ }^{14}$, Chiara Montagna ${ }^{2}$, Augusto Neri ${ }^{2}$, Eleonora Rivalta ${ }^{15}$, Gilberto Saccorotti ${ }^{2}$, Freysteinn Sigmundsson ${ }^{16}$, Laura Spina ${ }^{5}$, Jacopo Taddeucci ${ }^{17}$

${ }^{1}$ School of Earth and Environmental Sciences, University of Manchester, Manchester, UK

${ }^{2}$ Istituto Nazionale di Geofisica e Vulcanologia, Sezione di Pisa, Pisa, Italy

${ }^{3}$ Department of Earth Sciences, University of Geneva, Geneva, Switzerland

${ }^{4}$ Arizona State University, School of Earth and Space Exploration, Tempe, USA

5 Department of Earth and Environmental Sciences, Ludwig-Maximilians-Universität München, Munich, Germany

${ }^{6}$ Istituto Nazionale di Geofisica e Vulcanologia, Sezione di Bologna, Bologna, Italy

${ }^{7}$ School of Earth and Ocean Sciences, Cardiff University, Cardiff, UK

${ }^{8}$ Université Clermont Auvergne, CNRS, IRD, OPGC, Laboratoire Magmas et Volcans, Clermont-Ferrand, France

9 British Geological Survey, Edinburgh, UK

${ }^{10}$ Dipartimento di Scienze della Terra, Università degli Studi di Torino, Torino, Italy

${ }^{11}$ School of Environmental Sciences, University of Liverpool, Liverpool, UK

12 Department of Earth Sciences, Durham University, Durham, UK

${ }^{13}$ School of Earth Sciences, University of Bristol, Bristol, UK

${ }^{14}$ Institut de Physique du Globe de Paris, Volcanic Systems, Paris, France

${ }^{15}$ GeoForschungsZentrum, section Physics of Earthquakes and Volcanoes, Potsdam, Germany

${ }^{16}$ Nordic Volcanological Center, Institute of Earth Sciences, University of Iceland, Reykjavik, Iceland

${ }^{17}$ Istituto Nazionale di Geofisica e Vulcanologia, Sezione di Roma, Roma, Italy

Article history

Received May 18, 2017; accepted October 10, 2017.

Subject classification:

Volcanic conduit; Magma ascent; Volcanic activity; Experimental, theoretical and observational volcanology; Unsteadiness;

Disequilibrium; Uncertainty.

\section{ABSTRACT}

Processes occurring in volcanic conduits, the pathways through which magma travels from its storage region to the surface, have a fundamental control on the nature of eruptions and associated phenomena. It has been well established that magma flows, crystallizes, degasses, and fragments in conduits, that fluids migrate in and out of conduits, and that seismic and acoustic waves are generated and travel within conduits. A better understanding of volcanic conduits and related processes is of paramount importance for improving eruption forecasting, volcanic hazard assessment and risk mitigation. However, despite escalating advances in the characterization of individual conduit processes, our understanding of their mutual interactions and the consequent control on volcanic activity is still limited. With the purpose of addressing this topic, a multidisciplinary workshop led by a group of international scientists was hosted from 25 to 27 October 2014 by the Pisa branch of the Istituto Nazionale di Geofisica e Vulcanologia under the sponsorship of the MeMoVolc Research Networking Programme of the European Science Foundation. The workshop brought together the experimental, theoretical, and observational communities devoted to volcanological research. After 3 days of oral and poster presentations, breakout sessions, and plenary discussions, the participants identified three main outstanding issues common to experimental, analytical, numerical, and observational volcanology: un- 
steadiness (or transience), disequilibrium, and uncertainty. A key outcome of the workshop was to identify the specific knowledge areas in which exchange of information among the sub-disciplines would lead to efficient progress in addressing these three main outstanding issues. It was clear that multidisciplinary collaboration of this sort is essential for progressing the state of the art in understanding of conduit magma dy namics and eruption behavior. This holistic approach has the ultimate aim to deliver fundamental improvements in understanding the underlying processes generating and controlling volcanic activity.

\section{Introduction}

Magma travels in volcanic conduits from its storage region to the surface. Volcanic conduits therefore are the sites of processes such as magma vesiculation, crystallization, degassing and fragmentation, which have a direct impact on magma rheological properties and, as a consequence, on eruption initiation, cessation, intensity, magnitude, and on eruptive style transitions. A better understanding of the physical processes taking place in magmas ascending in volcanic conduits, will then help improving eruption forecasting, assessing volcanic hazard, and mitigating volcanic risk.

In the last decade, rapid technological developments in various fields of volcanology have greatly enhanced our ability to quantify a vast set of parameters at ever increasing spatial resolution, sampling and analytical rates. As an example, we report here a list of recent works which, embracing different techniques, have provided improvements in the following research fields: analytical [Metrich and Wallace 2008, Bachmann et al. 2010, Blundy et al. 2010, Mercier et al. 2010, Metrich et al. 2010, Edmonds et al. 2013], experimental [Kueppers et al. 2006, Ardia et al. 2008; Giordano et al. 2008, Lavallée et al. 2007, 2008, Caricchi et al. 2011, Cimarelli et al. 2011, Llewellin et al. 2011, Martel 2012, Lavallée et al. 2013, Okumura et al. 2013, Rivalta et al. 2013, Polacci et al. 2014, Kendrick et al. 2014a, Wadsworth et al., 2014, Giordano and Russell 2016, Kendrick et al. 2016, Kolzenburg et al. 2016a, b, Russell and Giordano 2016; Del Bello et al. 2017], numerical [Costa et al. 2007a, 2009, Maccaferri et al. 2010, 2011, Degruyter et al. 2012, Longo et al. 2012, de' Michieli Vitturi et al. 2013, Melnik and Costa 2014] and observational volcanology [Kueppers et al. 2005, Gurioli et al. 2008, Andronico et al. 2009, Gudmunsson et al. 2012, Polacci et al. 2012, Taddeucci et al. 2012, Cashman et al. 2013, Lavallée et al. 2015, Tuffen et al. 2013, Gaudin et al. 2016], volcano geophysics [Wright et al. 2012a, Harris 2013, Ripepe et al. 2013, Zuccarello et al. 2013, Bean et al. 2014, De Angelis et al. 2016] and geochemistry [Allard et al. 2005, Mori and Burton 2009, Oppenheimer et al. 2010,
Aiuppa et al. 2011, Gauthier et al. 2016]. However, processes controlling the eruptive volcanic activity that we observe at the Earth's surface occur in the conduit at depth, hidden from direct observation. Without a sound theoretical framework on which to improve our knowledge of deep conduit processes, our ability to understand volcanoes, predict their eruptions and mitigate their impacts, will always be deeply limited. Thus, developing robust physical models of the governing volcanic processes will greatly increase our ability to interpret their activity, and, ultimately, predict eruptions.

The purpose of this workshop was to address this issue head-on. We believe that the topics discussed will help the volcanological community to fully realize the potential of new technologies, and to deliver tangible improvements in volcanic risk assessment and reduction through increasing our knowledge of the underlying processes generating and controlling volcanic activity. With this in mind, the workshop participants were asked to specifically address the following fundamental questions that have concerned volcanologists for years:

1) What are the main physical parameters affecting conduit and eruptive processes, and what are the interactions between them?

2) How do conduit magma dynamics evolve during both quiescent and eruptive volcanic activity?

3) Why do transitions in eruptive style occur in conduits, and how can we model and predict them?

To address these questions, the workshop schedule was designed to follow a two-step procedure. First, 36 attendees from 7 different countries (Italy, France, Germany, United Kingdom, Switzerland, Iceland, and USA) critically reviewed background knowledge on conduit processes and eruption dynamics. They then combined their effort to propose a sound, multidisciplinary approach for pursuing novel studies on conduit processes and eruption behavior. To achieve this objective, the workshop consisted of 3 days of oral and poster presentations, breakout sessions, and plenary discussions, reviewing the state-of-the-art in the field. The workshop attendees were selected amongst a group of leading international scientists whose expertise covered the three main conduit-related methodological areas addressed by the workshop:

1. Volcano observations - i.e observations and measurements of natural volcanic systems and products;

2. Experiments - including textural and analytical characterization, high pressure/high temperature experimentation, and analogue modeling; 
3. Numerical modeling - including models focusing on fluid dynamics as well as on the mechanical response of the host rock.

Each methodological area was illustrated by three to five spokespersons that summarized the latest findings in the field, highlighted the limits and advantages of the methods, and proposed potential ways of integration with the other areas. For example, experimentalists and analytical/numerical modelers discussed:

i) the information they can provide on conduit processes;

ii) what they would need from the compositional, physical and textural sample characterization community and/or the geochemical/geophysical signal characterization community to improve the quality and feasibility of research studies in the area.

In addition, experimentalists illustrated what sort of information arising from their results can be used in numerical simulations of conduit magma ascent or dike propagation and eruption processes, as either input data or validation. Numerical modelers stated what output current models could provide (e.g. temporal and spatial evolution of magma ascent in volcanic conduits or dikes), and which experimental and observational data they need to better constrain model input and validate the codes. Finally, scientists working with direct measurements on volcanic systems, such as gas geochemists and geophysicists, suggested what measurements/parameters are available to integrate in both experiments and numerical models, and together with experimentalists and numerical modelers, proposed how to integrate them in the most synergistic and feasible manner. Ultimately, all participants worked together to define benchmarks to use as comparisons amongst numerical models and between numerical models and data coming from both experiments and observations. The outcome of the workshop was to produce this document, which describes a number of fundamental points to achieve a tangible improvement in the study of conduit processes and volcanic eruptions.

\section{Workshop themes}

\subsection{Volcano Observations}

The thematic group on Volcano Observations identified eight main topics where they made major contributions to the study of conduit processes. Amongst these topics, the group pointed out what can be achieved in the near future and what they need from the other thematic groups in order to improve their performance and meet the workshop goals.

\section{Deposit characterization}

Field measurements of pyroclastic deposits enable production of total grain size distributions (TGSDs) and particle density distributions (PDDs) [Bonadonna and Phillips 2003, Bonadonna and Houghton 2005, Costa et al. 2016, Eychenne and Le Pennec 2012, Bombrun et al. 2015]. It was stressed that more work ought to be conducted to quantify the types, abundances, particle sizes and distributions of non-juvenile particles (nomenclature from White and Houghton 2006) such as lithics, in order to better understand their implications for conduit processes, for example conduit stability and erosion [e.g., Shea et al. 2011, Bernard et al. 2014, Colombier et al. 2017]. A general point of discussion was the requirement to assess and present estimates of uncertainties and errors for measurements and observations, with a distinction between actual errors on a given measurement and those on inferred information, which have a larger uncertainty [e.g., Biass and Bonadonna 2011, Engwell et al. 2013]. Such distinction is of paramount importance, because errors and uncertainties feed through to estimates of other measurements and model results (for example, tephra volume, TGSDs, PDDs and dispersion modeling) [Burden et al. 2011, Engwell et al. 2015, see also discussion in Gurioli et al. 2015].

Achievable goals from deposit measurements in the near future include:

- Better classification of total particle size distribution and measurement of variations of density (e.g., for weather radar data inversion).

- Provide better data for inversion of numerical models, especially taking into account time variations and different eruption phases.

- Ground measurements of particle flux and velocity time variations in sedimentation rate.

- Quantifying abundances and variations of different pumice types, e.g. tube pumice, and pumices containing micro-brecciated crystal populations, which may derive from near the conduit wall.

$\underline{\text { Remote sensing measurements of eruption source }}$ parameters from volcanic conduits

Remote sensing techniques and instruments allow us to obtain measurements of eruption source parameters. Parameters as plume exit velocity and trajectory, mass discharge rates, gas fluxes, gas compositions, and grain size distributions can now be measured in real time using high-speed visual, thermal, infrared and sulfur dioxide cameras [Bani et al. 2013, Harris 2013, Bombrum et al. 2014, Gaudin et al. 2014a, b, Valade et al. 2014, Barni et al. 2015, Bombrum et al. 2015, Burton et 
al. 2015, Cerminara et al. 2015, Bombrun et al. 2016, Gaudin et al. 2016], a combination of thermal camera, weather radar observations and/ or infrasound measurements [Lamb et al. 2015, De Angelis et al. 2016, Vulpiani et al. 2016], and open-path Fourier transform infrared (OP-FTIR) spectrometry [La Spina et al. 2015, Allard et al. 2016]. These measurements have highlighted the unsteady nature of these parameters. Plume imagery through combined monitoring techniques is able to provide mass concentration, instantaneous particle grain size distribution, and particle sedimentation rate to the ground. Time variations of plume height can also be obtained as an estimate of mass flux, while the plume expansion rate can be used to estimate plume entrainment coefficient. Multi-parametric monitoring of charge distribution and frequency of electrical discharges in plumes during explosive eruptions [Cimarelli et al., 2016] are starting to systematically address the links between the in-conduit explosive dynamics and the electrification of volcanic ash with the goal of constraining mass eruption rates and plume evolution in space and time. In addition, the new instruments and technologies mentioned above allow measurement of ejection velocities at higher spatial and temporal resolutions, as well as the degree of decoupling of solids and gas phases in jets [e.g., Taddeucci et al. 2012, Scharff et al. 2014, Taddeucci et al. 2015] and, recently, the effect of particle volume fraction on the ash settling velocities [Del Bello et al. 2017]. Finally, participants highlighted the importance of distinguishing between plume and conduit dynamics, especially concerning how much can be inferred regarding the latter from observations of the former.

Achievable remote sensing goals in the near future include:

- Quantifying volcanic ash loading and its temporal and spatial evolution, coupled with ground-truthing strategies.

- Estimating total particle size distribution from multiparametric plume imagery.

- Application of these techniques to larger (e.g., Plinian) eruptions.

\section{Surface deformation measurements}

Pressurization processes in established eruption conduits typically result in highly localized and small deformation signals that can only be captured by continuously operating high-resolution observations such as a combination of small-scale strain and tilt meter measurements [e.g., Voight et al. 1999, Anderson et al. 2010, Albino et al. 2011]. Pre-eruptive intrusions in volcanoes, which can develop into established con- duits, generally cause larger deformation signals over wide areas. In such cases, geodetic techniques such as Global Positioning System (GPS), with good temporal resolution, and synthetic aperture radar images (InSAR), with good spatial resolution, are well suited to capture the resulting surface deformation signals [e.g., Sigmundsson et al. 2010, 2015, Gudmundsson et al. 2016]. Accordingly, a combination of techniques needs to be applied to cover different temporal and spatial scales to study conduit processes. Time variations of surface deformation have been used as a measure of pressure variation in the reservoir, although this is applicable only to larger events and is more difficult to use for smaller eruptions, unless instrument location can be proximal, in which case minute ground deformation signals may provide excellent constraints on eruption style [Lavallée et al., 2015]. Furthermore, strong assumptions on the rheologi$\mathrm{cal} /$ mechanical parameters of the host rock (such as elasticity) are necessary to obtain information on pressurization. Correlations between surface deformation and flux measurements from plume height have been observed for the 2010 Grímsvötn eruption, Iceland [Hreinsdóttir et al. 2014] and applied in Japan [Kozono et al. 2014], and this may be useful in future eruptions. In addition, surface deformation and gravity measurements can be coupled to constrain the nature of the pressurization source [e.g., Bagnardi et al. 2014, Carbone et al. 2015], or the magma reservoir processes responsible for variations in volume within the plumbing system [Caricchi et al. 2014, Parker et al. 2016]. Finally, strain fields can be used to reveal conduit geometry and provide constraints on the size of a reservoir and dike intrusions.

An achievable goal from surface deformation measurements in the near future is

- Improving techniques for modeling pressure source geometries and incorporation of constraints from volcano geodesy into models of conduit processes.

\section{Muon tomography}

Recent advance in muon tomography allows us to image shallower parts of conduits with resolutions on the scale of several tens of meters, and the technique is being developed and tested by groups in Japan, France and Italy [Tanaka et al. 2009, Lesparre et al. 2012, Anastasio et al. 2013, Ambrosino et al. 2015, Tioukov et al. 2017]. It is based on the absorption of cosmogenic muons by the volcanic edifice, allowing the mapping of density variations within it. However, this methodology is under development and still requires validation by other measurement types. 


\section{$\underline{\text { Seismic and acoustic measurements }}$}

The dynamic interaction of gas, liquid and solid phases in conduits originates a wide spectrum of seismic events. The complex shape of conduits may control flow disturbances and represents a primary factor in providing sites where pressure and momentum changes are effectively coupled to the Earth [Chouet and Matoza, 2013]. Hence, seismic techniques can be used to map the propagation of dikes and fractures (e.g. as for the 2014-2015 Bardarbunga eruption [Sigdmunsson et al. 2015]), to follow conduit formation [e.g., Tarasewicz et al. 2012, Ágústdóttir et al. 2016], and track the transport of magma and exsolved fluids during eruption [Kendrick et al. 2014b, Lamb et al. 2015]. Seismic tomography is currently used to image magma reservoirs at the base of the conduit [Lees 2007, Koulakov 2013, Lin et al. 2014]. The study of LP seismicity (LP events and tremor) and VLP events provides information on several processes related to magma transport and on the pathway geometry of magma ascent [e.g. Cannata et al. 2009].

In the last two decades, the investigation of the acoustic field related to eruptive processes has increasingly become a valuable tool for monitoring and research purposes. A variety of source processes is capable of producing acoustic waves; to cite a few: bursting of gas slugs, conduit resonance, and jet noise [e.g. Fee and Matoza 2013, and references therein]. Because jet noise is directly related to conduit processes, infrasound provides information on pressure, mass flux and velocity variations during eruptions [Johnson and Ripepe 2012, and references therein]. Finally, the integration of seismic and acoustic techniques provides estimates of energy partitioning, which depends on several factors such as magma properties, fragmentation depth and conduit obstruction [e.g. Andronico et al. 2013].

An achievable goal from seismic measurements in the near future is:

- A deep comprehension of the link between the physical processes in terms of flow dynamics and location, magnitude, focal mechanism and frequency content of observed earthquakes and other seismic signals.

\section{Pre-eruptive and residual volatile content}

When degassing occurs at equilibrium, gas species ratios are sensitive to magma storage pressure, ascent rates, and ascent history. If we know the original (dissolved + exsolved) and residual (after vesiculation) gas contents, we can use gas flux as a proxy for magma flux, provided that the eruption is supplied by a single magma batch and no mixing or gas segregation has oc- curred. In addition, gases can reveal contributions from deep and shallow magmas.

Achievable goals from volatile measurements in the near future are:

- A thorough investigation of disequilibrium degassing and its effects on magma and eruption dynamics.

- A better understanding of the effects and deep abundance of $\mathrm{CO}_{2}$; currently we are not able to evaluate the amount of $\mathrm{CO}_{2}$ that can enter the system.

- A better understanding of how brines affect gas signatures at the surface.

- A better understanding of abundances and compositions of free vapor phases at depth. This information provides insights on what is controlling phase transitions, transitions in eruptive style, and the arrival of new magma.

\section{Petrological measurements}

The participants pointed out that we are currently underutilizing mineralogy to gain information regarding magma transport and ascent properties. This information is, for example, recorded in mineral composition and zoning patterns (see, for example, articles cited in Putirka and Tepley 2008).

A number of measures can be taken in the near future to increase and improve the information that petrological measurements can provide, with the following aims:

- Improve the use of thermodynamic models for calculating crystal-melt equilibrium and disequilibrium (e.g. geothermobarometry).

- Conduct studies on species diffusion ( $\mathrm{Li}_{2} \mathrm{H}_{2} \mathrm{O}$, etc.) to determine magma storage and ascent timescales.

- Perform better studies of crystal morphology for acquiring information on crystal formation and growth. - Conduct experiments on the effects of strain rates on crystal nucleation and growth rates.

- Improve the integration of petrography with gas measurements.

\section{Textural measurements on samples}

Textural data provide information on magma pressure and thermal histories in conduits and plumes. For example, vesicle number densities (VNDs; i.e., the number of vesicles per unit bulk volume) provide estimates of magma decompression rates [Toramaru 2006, Shea et al. 2011, Wright et al. 2012b] and eruption intensities [Rust and Cashman 2011, Alfano et al. 2012], while crystal size distributions (CSDs) and vesicle size distributions (VSDs) (i.e., the number of crystals or vesicles in each size class per unit bulk volume) provide information on crystallization and differentiation in magma reservoirs 
and conduits [Fornaciai et al. 2009, Shea et al. 2009, Brugger and Hammer 2010, Arzilli and Carroll 2013], and on magma vesiculation [Bai et al. 2008, Gurioli et al. 2008, Colò et al. 2010, Shea et al. 2010, Carey et al. 2012], permeability [Mueller et al. 2008, Bouvet de Maissoneuve et al. 2009, Wright et al. 2009, Polacci et al. 2014, Heap et al. 2014, Kendrick et al. 2016, Colombier et al. 2017], and degassing/outgassing [Burton et al. 2007, Degruyter et al. 2010a, 2012]. Furthermore, VSDs, CSDs, melt chemistry and volatile content feed into magma rheology estimates [Mader et al. 2013, Vona et al. 2013]. Heterogeneities in conduit stratigraphy (vertical, horizontal and time-varying) should not be underestimated [Cimarelli et al. 2010] and nowadays can be determined from analysis of the entire pyroclastic size range, including ash [Miwa et al. 2013, Cioni et al. 2014, Liu et al. 2015a], lapilli [Shea et al. 2014] and bombs [Wright et al. 2007, Gurioli et al. 2014, Leduc et al. 2015, Lavallée et al. 2017]. The workshop participants highlighted the necessity to better understand what information is gained from the study of different types and size of pyroclasts. 3D imaging via conventional and synchrotron-based X-ray computed microtomography as well as neutron computed tomography offers the ability to image and quantify rock textures directly in 3D in unprecedented detail [Baker et al. 2012 and references therein, Lavallée et al. 2013, Arzilli et al. 2016]. Through 3D textural investigations we are able to view structures that are the result of strain localization [Wright and Wimberg 2009, Shields et al. 2014, Dingwell et al. 2016], deformation [Okumura et al. 2010; Caricchi et al. 2011, Pistone et al. 2012, Ashwell et al. 2015], crystal aggregation and crystal fragmentation [Pamukcu et al. 2012], convection [Polacci et al. 2012, Carey et al. 2013] and development of permeability [Bai et al. 2010, Degruyter et al. 2010b, Bai et al. 2011, Kendrick et al. 2013, Lavallée et al. 2013, Ashwell et al. 2015] in magma, which can be related to experiments, and which in the near future could feed into experimental and numerical modeling. Finally, information on fragmentation mechanisms (the terms "phreatic", "hydrothermal", and "hydromagmatic" are cause of great amount of discussion and debate about their meaning and use) can, in part, be assessed from particle morphology [Dellino et al. 2012, Jordan et al. 2014, Liu et al. 2015b], while TGSD provide information on fragmentation efficiency [Kueppers et al. 2006, Rust and Cashman 2011, Costa et al. 2016]. However, particle morphology alone is not a proxy for the fragmentation mechanism; the textural state rather shows the state of magma upon quenching, following fragmentation. Additionally, care is required as aerodynamic properties may lead to transport-related sorting (and possibly splitting of textural groups). Accordingly, particle characterization should always be done on deposits from several outcrops in proximal and distal locations, on the dispersal axis and away from it.

What the group Volcano Observations needs from the other thematic groups

From the group Experiments

- 4D (3D + time) experiments on magma flow and evolution in felsic and mafic magmas.

- Larger-scale experiments on vesiculation and crystallization.

- Experiments on disequilibrium degassing and crystallization.

- Experiments on strain accommodation in threephase magmas.

- Experiments on a range of fragmentation behaviors.

- Experiments on viscous heating in high (and low) viscosity systems, in order to target shearing processes near the conduit wall.

- Experiments to elucidate the source mechanisms of tremor, LP and VLP events, linking physical processes in terms of flow dynamics with location, magnitude, focal mechanism and frequency content of observed earthquakes and other seismic signals.

- Larger-scale fluid dynamics experiments (higher Re, different dynamics, etc.).

- Mixed-volatile experiments.

From the group Numerical Modeling

- Models coupling reservoir and conduit with which to invert data from surface deformation and eruption rate.

- Modeling of processes and signals associated with rise, pressurization and bursting of gas slugs in a conduit.

- Numerical experiments to access the scaling laws governing large-scale effects (e.g. unsteadiness). - Improvement of fallout inversion models.

From both Experiments and Numerical Modeling - Laboratory and numerical experiments capturing transient phenomena in general.

- Laboratory and numerical experiments on laws governing bubble coalescence.

\subsection{Experiments}

The group Experiments focused their discussion on general topics related to conduit dynamics, as well as on the general and specific needs they require from the two other thematic groups in order to deliver tangible improvements on the study of conduit processes both in the near future and long term. The group recognized 
unanimously that the principal physical control on eruption style and explosivity is, besides gas content, magma rheology. In this view, it was stated that a major objective for experimentalists in the near future is to perform experiments allowing determination of the fundamental constitutive equations for three-phase magmas with bubble and crystal contents over the volcanologically relevant range [Pistone et al. 2012, Mader et al. 2013, Truby et al. 2014]. The group also highlighted the importance of strain-localization and viscous heating in conduits. The former affects the ductile-brittle transition and pore redistribution in magmas [Wright and Weinberg 2009, Lavallée et al. 2013], while the latter is responsible for the onset of much of the Non-Newtonian behavior commonly observed in magmas [Cordonnier et al. 2012] and controls magma flow dynamics in conduits [Costa et al. 2007a]. Both are ubiquitous and unavoidable phenomena, and yet they still need to be properly quantified in magmas. Amongst general needs, the participants claimed a requirement for 4D dynamically evolving experiments that can be compared with both field data and numerical simulations. There is a need to consider how to integrate data coming from different experiments, as well as how to apply different techniques, at different scales. For example, how can recording of acoustic emissions during laboratory deformation of samples be used as analog of seismicity in natural systems? Experiments on simplified analog systems are also needed to separate otherwise intricate effects, test hypotheses and define the important parameters of a process [Namiki and Manga, 2008, Namiki et al. 2014, Namiki et al. 2016, Spina et al. 2016a]. For instance, large-scale analog experiments can unveil complexities in the conduit of maar-diatreme volcanoes [Valentine et al. 2012, Taddeucci et al. 2013]. There is also a need to develop probabilistic approaches to experimentation, where, for instance, experiments are repeated to identify variability in the process (for example to determine if experimental results can be reproduced or if there is critical sensitivity to starting conditions). Experimentalists need to consider dynamic tracers to determine the evolution of a sample/particle to produce the final characteristics observed. In terms of physical versus geochemical observations, we need to take into account geochemical parameters and related information when conducting physical experiments. To this end, well-instrumented field campaigns at accessible volcanoes (e.g. Stromboli) can be used to bridge the gap between controlled-setting experiments, modeling, and sparse observations. In addition, we need to develop a strategy for sample exchange such that different groups working on the same set of samples can determine different parameters. Ultimately, this can be used as a way of communicating among different groups. Finally, because experiments are an excellent way to test numerical models, experimentalists need to know what numbers/parameters and degree of precision are required by modelers in order for them to be able to validate their results.

What the group Experiments needs from the other thematic groups

From the group Numerical Modeling

- Development of numerical models capable of reproducing unsteadiness in natural systems.

- Development of numerical models capable of accounting for layered systems (for example, gradients of localized stresses).

- Development of numerical models capable of simulating processes that occur within conduits of irregular geometry.

From the group Volcano Observations

- Better information regarding emplacement conditions, which is related to the description of deposits.

\subsection{Numerical modeling}

The group Numerical Modeling focused mainly on what physical processes are important to address/take into account in the study of conduit magma ascent to improve knowledge in the near future, and what they require from the other thematic groups. One of the main problems identified by this group is that currently there is a division in two main groups of models: those that address the flow of magma in cylindrical, established conduits, and those considering magma pathways where magma forces its way through the rock by means of hydraulic fracturing (diking). The former focus on fluid dynamics neglecting the mechanical response of the host rock; simplified conduit shapes are assumed that may significantly deviate from those in the real system [Ramos 1999, Melnik 2000, Mastin 2002, Melnik et al. 2005, Gonnermann and Manga 2007]. The latter consider the mechanical response of the host rock and thus obtain realistic/physical dike/conduit shapes, but neglect or simplify drastically the physical properties of the magma [Rivalta and Segall 2008, Maccaferri et al. 2010, Rivalta 2010, Maccaferri et al. 2011, Maccaferri et al. 2015, 2016, Rivalta et al. 2015]. Conduit flow models ignore the coupling of the dike system to the solid (elastic) system [Costa et al. 2009, Melnik and Costa 2014, von der Lieth and Hort 2016]. Certainly, the over- 
all field of numerical modeling of conduit processes would benefit from a better integration between the different groups. On the other hand, there is room to integrate more realistic magma properties and presence of bubbles or volatiles in diking models. In order to progress in these respects, we need to build a larger network of modelers who are efficiently collaborating to define a general framework from which models can build upon.

Finally, this group recognized the importance to deal with uncertainties. Often people from both the experimental and decision-making communities do not consider that some estimates in the modelling can have an uncertainty of a factor of 10 or larger. The geometry of the volcanic system is very important and very hard to infer, and there are huge uncertainties associated with it, for example, the size of magma chambers and conduits [Costa et al. 2007b, de' Michieli Vitturi et al. 2008, Colucci et al. 2014, Melnik and Costa 2014]. For some volcanic systems, geophysical data collected during eruptions indicate the presence of one or multiple magma storage regions connected with a conduit [Hautmann et al. 2010], and numerical models are now beginning to simulate these complex geometric configurations [Melnik and Costa 2014]. Moreover, dike pathways through the crust may not be vertical [Lamb et al. 2015] and may not coincide with pre-existing weaknesses in the host rock as is often assumed [Rivalta et al. 2015]. Dike pathways are often tortuous as evidenced by recent studies [Bagnardi et al. 2013] and strongly influenced by the distribution of surface loads [Maccaferri et al. 2014, Maccaferri et al. 2015, Corbi et al. 2015, 2016], layering [Rivalta et al. 2005, Maccaferri et al. 2010] and faulting [Passarelli et al. 2015, Maccaferri et al. 2016]. In addition to this, there are problems with the terminology used to define magma chambers: there is confusion when we refer to what different techniques are detecting at different time scales. Different geochemical and geophysical processes evidence different spatial and temporal scales and volumes, with uncertainties of orders of magnitude. For example, different techniques have estimated the dimension of the summit magma chamber at Kilauea from a fraction of to tens of cubic $\mathrm{km}$. Another important point discussed by the group participants is the importance of taking into account 1D, 2D or 3D models, as we need to balance the computational expense versus the number of runs required to properly explore the parameter space and conduct a proper sensitivity analysis [Collier and Neuberg 2006, Longo et al. 2012]. Other outstanding parameters/points discussed by numerical modelers to be considered in terms of modeling conduit processes are: closed versus open system degassing, lat- eral degassing, equilibrium and disequilibrium processes, conduit erosion and magma-water interaction, viscous heating, and heat loss effects [Macedonio et al. 1994, Mangan et al. 2004, Dufek and Bergantz 2005, Starostin et al. 2005, Diller et al. 2006, Costa et al. 2007a, Degruyter et al. 2010b, Degruyter et al. 2012, La Spina 2014]. Numerical modelers further recognized the importance to integrate their methods with experimental techniques. However, we need to understand to what extent such integration is possible and how well models can be benchmarked by the experiments. Ultimately, modelers need to identify what parameters are important so that experiments can be designed to constrain them (see also section 2.2 Experiments). One of the main limitations of the numerical approach that has hindered the interaction with experimentalists is the fact that models generally describe processes occurring at the macroscale and experiments on for example rheology or degassing are commonly conducted at the scale of hand samples or smaller. This leads to the use of averaged quantities such as effective viscosity or permeability, which do not capture heterogeneous effects occurring at the pore scale, such as shear localization or gas channel formation. In order to advance the comprehension of the processes occurring at the microscale and how these processes govern the macroscale dynamics of the eruption, all modelers agreed that the following processes, parameters and properties need an improved description to model conduit magma ascent: bubble and crystal shapes, size distributions, nucleation, growth, deformation, degassing, permeability, rheology, reservoir (magma chamber)/ conduit size and geometry and elastic response of the host rock. One can study these microscale processes by using novel numerical methods [Parmigiani et al. 2016] or the technological advances that allow 4D experiments [Fife et al. 2012]. In theory, the use of population balance equations allows us to describe some of the relevant microscale processes at the macroscopic scale, but the computational costs for this approach are extremely high. In other fields, such as aerosol dynamics, the so-called method of moments has been shown to be a powerful tool to solve the population balance equation, and its application to the modelling of conduit processes is currently under investigation.

What the group Numerical modelling needs from the other thematic groups

From the group Numerical modeling:

- Better integration between different modeling groups, particularly between those focusing on conduit fluid dynamics and those focusing on 
the mechanical response of the rock.

From the group Volcano Observations and the group Experiments:

- Improved recognition of the importance and role of uncertainties.

- Better integration of their methods with experimental techniques, especially with the aim to understand how well models can be benchmarked by the experiments.

\section{Outstanding issues in modern volcanology and recipes to address them}

\subsection{Unsteadiness}

Most eruptions, over different time scales, present changes in their characteristics, such as transitions in the eruptive style or changes in the mass flow rate. From the workshop, it emerged that in general a unique definition of unsteadiness does not exist. Volcanic eruptions exhibit fluctuations at a range of timescales; long timescales (months to years) are generally associated with deeper processes reflecting conditions in the magma reservoir, whereas shorter timescale fluctuations are generally associated with conduit and eruptive processes. For instance, periodic activity in explosive episodes alternate with longer periods of rapid effusive dome growth (such as at the Soufrière Hills volcano on Montserrat in May-August 1997, or the 2010 eruptive sequence at Merapi Volcano in Indonesia) [de' Michieli Vitturi et al. 2013, Flower and Carn 2015, Carr et al. 2016]. Also, small eruptions have revealed that single explosions may be formed by multiple, discrete ejection pulses [Taddeucci et al. 2012, Gaudin et al. 2014a, b, Scharff et al. 2014] resulting in unsteadiness and, sometimes, cyclicity, at a much shorter frequency [Dominguez et al. 2016, Spina et al. 2016b]. Highly nonlinear relationships between magma shearing, degassing and crystallization, and magma permeability and pressurization of the shallow conduit system, or interaction of magma with ground water, control temporal transitions in eruptive style and unsteadiness in eruptive processes. For example, transition from periodic explosions to effusive activity may occur when sufficient permeable outgassing develops, reducing pressurization within the conduit [Melnik et al. 2005, Kozono and Koyaguchi 2009, Degruyter et al. 2012, Nguyen et al. 2014, Spina et al. 2016a]. Viscous heating near conduit margins [Costa et al. 2007a], and frictional heating along faults [Kendrick et al. 2014a, b], can locally change effective viscosity [Hess et al. 2008], crystallization, volatile exsolution [Lavallée et al., 2015], kinetics and gas loss [ Kendrick et al. 2013, Lavallée et al. 2013], which control magma flow cyclicity in lava dome eruptions [Lavallée et al. 2012], thus possibly resulting in transient changes in the flow regime. These complex relationships and the time scales at which the processes occur deserve further studies to improve our knowledge of the unsteady dynamic of magma flow within the volcanic conduit.

\subsection{Disequilibrium}

Understanding the processes controlling eruptive style is critical for volcanology and eruption forecasting. Eruptive style is controlled by coupling between gas and magma during magma ascent, with strong coupling leading to enhanced fragmentation and ash production and weak coupling promoting efficient outgassing and accordingly translating into milder effusive activity and lava emission. This coupling is controlled by the interplay and feedback among several non-linear processes such as multi-phase magma rheology and its evolution, crystallization, gas exsolution, permeability, magma ascent velocity and fragmentation, within a dynamic magma reservoir and conduit system. However, a crucial limitation of previous work is that such non-linearity has been predicated almost exclusively on the assumption of thermal and kinematic equilibrium between melt, crystals, and volatiles. Volcanologists have traditionally assumed that the processes of magma degassing and solidification/crystallization occur nearly instantaneously in response to depressurization associated with magma ascent and eruption. However, it is now recognized that the timescales required to achieve equilibrium for both crystal growth [Vona and Romano 2013; Kolzenburg et al. 2016a] and volatile exsolution [Pichavant et al. 2013, Rivalta et al. 2013, Lloyd et al. 2014] are often longer than the timescales of magma ascent. The impact of disequilibrium is profound because gas and crystal content control magma viscosity, density, ascent rate, and the fragmentation process. These parameters, in turn, control flow dynamics and eruption style - from explosive to effusive- which ultimately dictate the nature and scale of the hazard posed. Although disequilibrium processes are increasingly recognized as the controlling factors in large-scale eruption dynamics, quantifying them in volcanic systems remains an enormous challenge: the $\mathrm{P}, \mathrm{T}$, volatile content, melt composition and rate-ofascent parameter space is huge. So far, laborious petrological and rheological experiments requiring interruption and quenching were necessary to capture each individual data point. To overcome these shortcomings, and significantly improve our understanding and quantitative modeling of volcanic processes and 
their impacts, requires a thorough understanding of disequilibrium processes in volcanic systems. This implies integration of 4D high pressure and high temperature experiments on both the kinetics of magma crystallization and vesiculation and multiphase magma rheology, 3D modeling of conduit magma ascent and eruption evolution, and comparison/validation with observations of the natural volcanic system.

\subsection{Uncertainty}

Uncertainty plays a major role in volcanology particularly in the study of conduit processes. Because direct observations of subsurface magma ascent conditions and dynamics are not possible, we have to investigate this complex system dealing with incomplete and uncertain information. In terms of volcanic hazard, the community's understanding of the physical system is limited, and subsurface parameters (volatile contents, crystal content, temperature, pressure etc.) are not always well constrained or are constrained with significant uncertainty. Furthermore, the exact relationship between subsurface parameters and eruption style (effusive vs. explosive) and scale is also poorly constrained. This not only implies that it is impossible to predict eruption scenarios and their consequences deterministically, but also that inferences that can be drawn from observational data could be not unique. Thus, characterization and quantification of uncertainty (in observations, experiments and models) is a crucial element in order to properly understand conduit processes and their control on volcanic processes and eruptive activity.

Uncertainty arises in every measurement necessary in analytical, experimental and observational volcanology, due to instrumentation, data acquisition and reduction limitations, and facility and environmental effects. In addition, models (experimental or numerical) of complex natural processes such as magma ascent are idealizations requiring simplifications, not necessarily unique, of the complicated physics that lead to unavoidable uncertainty. Furthermore, it is important to understand how uncertainty in some variables or parameters, such as for example initial gas and crystal content, propagates in the uncertainty of system outputs, like conditions observed and measured at the vent. Because the source of uncertainty is present in all methodologies adopted to investigate conduit processes, and propagate from one approach to another, a multidisciplinary investigation is needed.

In the past, according to the field of interest, several classifications of the source of uncertainty have been adopted. Two different types of uncertainty are generally considered [Marzocchi et al. 2005]: aleatoric and epistemic. Aleatoric uncertainty is associated with the intrinsic complexity of the system that makes a deterministic prediction impossible, while epistemic uncertainty is associated with the limited knowledge of the system and can be, in principle, reduced improving our comprehension of the system or increasing the accuracy of data. Another way to classify uncertainty in a system is illustrated in Vernon et al. [2010], where the following basic uncertainties are described: observational uncertainty, parameter uncertainty, simulator uncertainty, input uncertainty and structural uncertainty.

\section{Conclusive remarks}

The main result of the workshop was to identify the specific knowledge areas in which exchange of information among the sub-disciplines would lead to efficient progress in addressing the three main outstanding issues that the participants identified common to experimental, analytical, numerical, and observational volcanology: unsteadiness (or transience), disequilibrium, and uncertainty. All workshop participants agreed that multidisciplinary collaboration of this sort is essential for progressing the state of the art in understanding of conduit magma dynamics and eruption behavior.

Acknowledgements. We would like to acknowledge the MeMoVolc Research Networking Programme of the European Science Foundation for funding the workshop. We are also deeply grateful to the University of Pisa and the INGV Pisa office for hosting the workshop and handling the logistics associated with it. A special thank goes to Renata Rapuzzi and Patrizia Pantani for their precious help with all aspects of the workshop organization.

\section{References}

Ágústsdóttir, T., J. Woods, T. Greenfield, R. G. Green, R. S. White, T. Winder, B. Brandsdóttir, S. Steinthórsson and H. Soosalu (2016). Strike-slip faulting during the 2014 Bárðarbunga-Holuhraun dike intrusion, central Iceland, Geophys. Res. Lett., 43, 1495-1503. doi:10.1002/2015GL067423.

Aiuppa, A., M. R. Burton, P. Allard, T. Caltabiano, G. Giudice, S. Gurrieri, M. Liuzzo and G. Salerno (2011). First observational evidence for the $\mathrm{CO}_{2}$ driven origin of Stromboli's major explosions, Solid Earth, 2, 135-142. doi:10.5194/se-2-135-2011.

Albino, F., V. Pinel, H. Massol and M. Collombet (2011). Conditions for detection of ground deformation induced by conduit flow and evolution, J. Geophys. Res., 116, B06201. doi:10.1029/2010JB007871.

Alfano F., C. Bonadonna and L. Gurioli (2012). Insights on rhyolitic eruption dynamic from textural analy- 
sis: the example of the May Chaitén eruption (Chile), Bull. Volcanol., 74(9), 2095-2108. doi:10.1007/ s00445-012-0648-3.

Allard, P., M. R. Burton and F. Mure (2005). Spectroscopic evidence for a lava fountain driven by previously accumulated magmatic gas, Nature, 433(7024), 407-410. doi:10.1038/nature03246.

Allard, P., M. R. Burton, G. Sawyer, and P. Bani (2016). Degassing dynamics of basaltic lava lake at a topranking volatile emitter: Ambrym volcano, Vanuatu arc, Earth Planet. Sci. Lett., 448, 69-80 12. doi:10.1016/j.epsl.2016.05.014.

Ambrosino, F., A. Anastasio, A. Bross, S. Béné, P. Boivin, L. Bonechi, C. Cârloganu, R. Ciaranfi, L. Cimmino, Ch. Combaret, R. D'Alessandro, S. Durand, F. Fehr, V. Français, F. Garufi, L. Gailler, Ph. Labazuy, I. Laktineh, J.-F. Lénat, V. Masone, D. Miallier, L. Mirabito, L. Morel, N. Mori, V. Niess, P. Noli, A. Pla-Dalmau, A. Portal, P. Rubinov, G. Saracino, E. Scarlini, P. Strolin and B. Vulpescu (2015). Joint measurement of the atmospheric muon flux through the Puy de Dôme volcano with plastic scintillators and Resistive Plate Chambers detectors, J. Geophys. Res., 120, 7290-7307. doi:10.1002/2015JB011969.

Anastasio, A., F. Ambrosino, D. Basta, L. Bonechi, M. Brianzi, A. Bross, S. Callier, A. Caputo, R. Ciaranfi, L. Cimmino, R. D'Alessandro, L. D'Auria, C. de La Taille, S. Energico, F. Garufi, F. Giudicepietro, A. Lauria, G. Macedonio, M. Martini, V. Masone, C. Mattone, M.C. Montesi, P. Noli, M. Orazi, G. Passeggio, R. Peluso, A. Pla-Dalmau, L. Raux, P. Rubinov, G. Saracino, E. Scarlini, G. Scarpato, G. Sekhniaidze, O. Starodubtsev, P. Strolin, A. Taketa, H.K.M. Tanaka and A. Vanzanella (2013). The MURAY detector for muon radiography of volcanoes, Nuclear Instruments and Methods in Physics Research, Section A: Accelerators, Spectrometers, Detectors and Associated Equipment, 732, 423-426. doi:10.1016/j.nima.2013.05.159.

Anderson, K., M. Lisowski and P. Segall (2010). Cyclic ground tilt associated with the 2004-2008 eruption of Mount St. Helens, J. Geophys. Res., 115, B11201. doi:10.1029/2009JB007102.

Andronico, D., L. Castro, M. Sciotto and L. Spina (2013). The 2010 ash emissions at the summit craters of Mt Etna: Relationship with seismo-acoustic signals, J. Geophys. Res., 118, 51-70. doi:10.1029/2012JB009895.

Andronico, D., A. Cristaldi, P. Del Carlo and J. Taddeucci (2009). Shifting styles of basaltic explosive activity during the 2002-03 eruption of Mt. Etna, Italy, J. Volcanol. Geotherm. Res., 180, 110-122. doi:10.1016/j.jvolgeores.2008.07.026.

Ardia P., D. Giordano, M.W. Schmidt (2008). A model for the viscosity of rhyolite as a function of $\mathrm{H}_{2} \mathrm{O}$ content and pressure: a calibration based on centrifuge piston cylinder experiments, Geochim. Cosmochim. Acta, 72, 6103-6123. doi:10.1016/j.gca.2008.08.025.

Arzilli, F. and M. R. Carroll (2013). Crystallization kinetics of alkali feldspars in cooling and decompression-induced crystallization experiments in trachytic melt, Contrib. Mineral. Petrol., 166, 1011-1027. doi:10.1007/s00410-013-0906-1.

Arzilli, F., M. Polacci, P. Landi, D. Giordano, D. R. Baker and L. Mancini (2016). A novel protocol for resolving feldspar crystals in synchrotron X-ray microtomographic images of crystallized natural magmas and synthetic analogs, Am. Mineral., 101 (10), 23012311. doi:10.2138/am-2016-5788.

Ashwell, P. A., J. E. Kendrick, Y. Lavallée, B. M. Kennedy, K. -U. Hess, F. W. von Aulock, F. B. Wadsworth, J. Vasseur and D. B. Dingwell (2015). Permeability of compacting porous lavas, J. Geophys. Res. Solid Earth, 120, 1605-1622. doi:10.1002/2014JB011519.

Bachmann, O., B. Schoene, C. Schnyder and R. Spikings (2010). 40Ar/39Ar and $\mathrm{U} / \mathrm{Pb}$ dating of young rhyolites in the Kos-Nisyros volcanic complex, Eastern Aegean Arc (Greece): age discordance due to excess 40Ar in biotite, G3, 11, Q0AA08. doi:10.1029/2010GC003073.

Bagnardi, M., M. P. Poland, D. Carbone, S. Baker, M. Battaglia and F. Amelung (2014). Gravity changes and deformation at Killuea Volcano, Hawaii, associated with summit eruptive activity, 2009-2012. J. Geophys. Res. Solid Earth, 119, 7288-7305. doi:10.1002/2014JB011506.

Bai, L., D. R. Baker and M. Rivers (2008). Experimental study of bubble growth in Stromboli basalt melts at 1 atm, Earth Planet. Sci. Lett., 267, 533-547. doi:10.1016/j.epsl.2007.11.063.

Bai, L., D. R. Baker and R. J. Hill (2010). Permeability of vesicular Stromboli basaltic glass: Lattice Boltzmann simulations and laboratory measurements, J. Geophys. Res., 115. doi:10.1029/2009JB007047.

Bai, L., D. R. Baker, M. Polacci and R. J. Hill (2011). Insitu degassing study on crystal-bearing Stromboli basaltic magmas: Implications for Stromboli explosions, Geophys. Res. Lett., 38 doi:10.1029/2011GL048540.

Baker, D. R., L. Mancini, M. Polacci, M. D. Higgins, G. A. R. Gualda, R. J. Hill and M. L. Rivers (2012). An introduction to the application of X-ray microto- 
mography to the three-dimensional study of igneous rocks, Lithos, 148, 262-276. doi:10.1016/j.lithos.2012.06.008.

Bani, P., A. Harris, H. Shinohara and F. Donnadieu (2013). Magma dynamics feeding Yasur's explosive activity observed using thermal infrared remote sensing, Geophys. Res. Lett., 40, 3830-3835. doi:10.1002/grl.50722.

Barnie, T., M. Bombrun, M. R. Burton, A. Harris and G. Sawyer (2015). Quantification of gas and solid emissions during Strombolian explosions using simultaneous sulphur dioxide and infrared camera observations, J. Volcanol. Geotherm. Res., 300, 167174. doi:10.1016/j.jvolgeores.2014.10.003.

Bean, C. J., L. de Barros, I. Lokmer, J-P. Metaxian, G. O’Brien and S. Murphy (2014). Long-period seismicity in the shallow volcanic edifice formed from slow-rupture earthquakes, Nat. Geosci., 7, 71-75. doi:10.1038/ngeo2027.

Bernard, J., K. Kelfoun, J-L. Le Pennec and S. Vallejo Vargas (2014). Pyroclastic flow erosion and bulking processes: comparing field-based vs. modeling results at Tungurahua volcano, Ecuador, Bull. Volcanol., 76, 858. doi:10.1007/s00445-014-0858-y.

Biass, S. and C. Bonadonna (2011). A quantitative uncertainty assessment of eruptive parameters derived from tephra deposits: the example of two large eruptions of Cotopaxi volcano, Ecuador, Bull. Volcanol., 73, 73-90. doi:10.1007/s00445-010-0404-5.

Blundy, J., K. V. Cashman, A. Rust and F. Witham (2010). A case for $\mathrm{CO}_{2}$-rich arc magmas, Earth Planet. Sci. Lett., 290, 289-301. doi:10.1016/j.epsl.2009.12.013.

Bombrun, M., V. Barra and A. Harris (2014). Algorithm for particle detection and parameterization in highframe-rate thermal video, J. Appl. Rem. Sens., 8, 083549, 1. doi:10.1117/1.JRS.8.083549.

Bombrun, M., A. Harris, L. Gurioli, J. Battaglia and V. Barra (2015). Anatomy of a Strombolian eruption: inferences from particle data recorded with thermal video, J. Geophys. Res. Solid Earth, 120, 2367-238. doi:10.1002/2014JB011556.

Bombrun, M., L. Spampinato, A. Harris, V. Barra and T. Caltabiano (2016). On the transition from strombolian to fountaining activity: a thermal energy-based driver, Bull. Volcanol., 78, 15. doi:10.1007/s00445016-1009-4.

Bonadonna, C. and B. F. Houghton (2005). Total grainsize distribution and volume of tephra-fall deposits, Bull. Volcanol., 67, 441-456. doi:10.1007/ s00445-0040386-2.

Bonadonna, C. and J. C. Phillips (2003). Sedimentation from strong volcanic plumes, J. Geophys. Res. Solid Earth, 108, 2340. doi:10.1029/2002JB002034.

Bouvet de Maisonneuve, C., O. Bachmann and A. Burgisser (2009). Characterization of juvenile pyroclasts from the Kos Plateau Tuff (Aegean Arc): insights into the eruptive dynamics of a large rhyolitic eruption, Bull. Volcanol., 71, 643-658. doi:10.1007/ s00445-008-0250-x.

Brugger, C. R. and J. E. Hammer (2010). Crystal size distribution analysis of plagioclase in experimentally decompressed hydrous rhyodacite magma, Earth Planet. Sci. Lett., 300, 246-254. doi:10.1016/j.epsl.2010.09.046.

Burden, R. E., J. C. Phillips and T. K. Hincks (2011). Estimating volcanic plume heights from depositional clast size, J. Geophys. Res. Solid Earth, 116, B11206. doi:10.1029/2011JB008548.

Burton, M. R., H. M. Mader and M. Polacci (2007). The role of gas percolation in quiescent degassing of persistently active volcanoes, Earth Planet. Sci. Lett., 264, 46-60. doi:10.1016/j.eps1.2007.08.028.

Burton, M. R., G. G. Salerno, L. D'Auria, T. Caltabiano, F Mure and R. Maugeri, R (2015). SO2 flux monitoring at Stromboli with the new permanent INGV SO2 camera system: A comparison with the FLAME network and seismological data, J. Volcanol. Geotherm. Res., 300, 95-102. doi:10.1016/j.jvolgeores.2015.02.006.

Cannata, A., M. Hellweg, G. Di Grazia, S. Ford, S. Alparone, S. Gresta and D. Patanè (2009). Long period and very long period events at Mt. Etna volcano: Characteristics, variability and causality, and implications for their sources, J. Volcanol. Geotherm. Res., 187, 227-249. doi:10.1016/j.jvolgeores.2009.09.007.

Carbone, D., L. Zuccarello, A. Messina, S. Scollo and H. Rymer (2015). Balancing bulk gas accumulation and gas output before and during lava fountaining episodes at Mt. Etna, Sci. Rep., 5, 18049. doi:10.1038/srep18049.

Carey, R. J., M. Manga, W. Degruyter, D. Swanson, B. F. Houghton, T. Orr and M. Patrick (2012). Externally triggered renewed bubble nucleation in basaltic magma: The 12 October 2008 eruption at Halema'uma'u Overlook vent, Kīlauea, Hawai'i, USA, J. Geophys. Res., 117, B11202. doi:10.1029/2012JB009496.

Carey, R. J., M. Manga, W. Degruyter, H. Gonnermann, D. Swanson, B. F. Houghton, T. Orr and M. Patrick (2013). Convection in a volcanic conduit recorded by bubbles, Geology, 41, 395-398. doi:10.1130/G33685.1 Caricchi, L., A. Pommier, M. Pistone, J. M. Castro, A. 
Burgisser and D. Perugini (2011). Strain-induced magma degassing: insights from simple-shear experiments on bubble bearing melts, Bull. Volcanol., 73, 1245-1257. doi:10.1007/s00445-011-0471-2.

Caricchi, L., J. Biggs, C. Annen, and S. Ebmeier (2014). The influence of cooling, crystallisation and remelting on the interpretation of geodetic signals in volcanic systems, Earth Planet. Sci. Lett., 388, 166174. doi:10.1016/j.epsl.2013.12.002.

Carr, B. B., A. B. Clarke and L. Vanderkluysen (2016). The 2006 lava dome eruption of Merapi Volcano (Indonesia): Detailed analysis using MODIS TIR, J. Volcanol. Geotherm. Res., 311, 60-71. doi:10.1016/j.jvolgeores.2015.12.004.

Cashman, K. V., S. A. Soule, B. H. Mackey, N. I. Deligne, N. D. Deardorff and H. R. Dietterich (2013). How lava flows: New insights from applications of lidar technologies to lava flow studies, Geosphere, 9, 1664-1680. doi:10.1130/ GES00706.1

Cerminara, M., T. Esposti Ongaro, S. Valade and A. Harris (2015). Volcanic plume vent conditions retrieved from infrared images: A forward and inverse modeling approach, J. Volcanol. Geotherm. Res., 300, 129-147. doi:10.1016/j.jvolgeores.2014.12.015.

Chouet, B. A., and R. S. Matoza (2013). A multi-decadal view of seismic methods for detecting precursors of magma movement and eruption, J. Volcanol. Geotherm. Res., 252, 108-175. doi:10.1016/j.jvolgeores.2012.11.013.

Cimarelli, C., F. Di Traglia, J. Taddeucci (2010). Basaltic scoria textures from a zoned conduit as precursors to violent Strombolian activity, Geology, 38; 439442. doi:10.1130/G30720.1.

Cimarelli, C, A. Costa, S. Mueller and H. M. Mader (2011). Rheology of magmas with bimodal crystal size and shape distributions: Insights from analogue experiments, G3, 12, Q07024. doi:10.1029/2011GC003606.

Cimarelli, C., M. A. Alatorre Ibargüengoitia, K. Aizawa, A. Yokoo and D.B. Dingwell (2016). Multiparametric observation of volcanic lightning: Sakurajima volcano, Japan. Geophys. Res. Lett., 43, 4221-4228. doi: 10.1002/2015GL067445.

Cioni, R., M. Pistolesi, A. Bertagnini, C. Bonadonna, A. Hoskuldsson and B. Scateni (2014). Insights into the dynamics and evolution of the 2010 Eyjafjallajökull summit eruption (Iceland) provided by volcanic ash textures, Earth Planet. Sci. Lett., 394, 111-123. doi: 10.1016/j.epsl.2014.02.051.

Collier, L. and J. Neuberg (2006). Incorporating seismic observations into 2D conduit flow modeling, J. Volcanol. Geotherm Res. 152, 331-46. doi:10.1016/j.jvolgeores.2005.11.009.

Colò, L., M. Ripepe, D. R. Baker and M. Polacci (2010). Magma vesiculation and infrasonic activity at Stromboli open conduit volcano, Earth Planet. Sci. Lett., 292, 274-280. doi:10.1016/j.epsl.2010.01.018.

Colombier, M., F. B. Wadsworth, L. Gurioli, B. Scheu, U. Kueppers, A. Di Muro and D. B. Dingwell (2017). The evolution of pore connectivity in volcanic rocks, Earth Planet. Sci. Lett., 462, 99-109. doi:10.1016/j.epsl.2017.01.011.

Colucci, S., M. de' Michieli Vitturi, A. Neri and D. M. Palladino (2014). An integrated model of magma chamber, conduit and column for the analysis of sustained explosive eruptions, Earth Planet. Sci. Lett., 404, 98-110. doi:10.1016/j.epsl.2014.07.034.

Corbi, F., E. Rivalta, V. Pinel, F. Maccaferri, M. Bagnardi, V. Acocella (2015). How caldera collapse shapes the shallow emplacement and transfer of magma in active volcanoes, Earth Planet. Sci. Lett., 431, 287-293. doi:10.1016/j.epsl.2015.09.028.

Corbi, F., E. Rivalta, V. Pinel, F. Maccaferri, V. Acocella (2016). Understanding the link between circumferential dikes and eruptive fissures around calderas based on numerical and analog models, Geophys. Res. Lett., 43, 6212-6219. doi:10.1002/2016GL068721.

Cordonnier, B., S. M. Schmalholz, K.-U. Hess, and D. B. Dingwell (2012). Viscous heating in silicate melts: An experimental and numerical comparison, J. Geophys. Res., 117, B02203. doi:10.1029/2010JB007982.

Costa, A., L. Pioli and C. Bonadonna (2016). Assessing tephra total grain-size distribution: Insights from field data analysis, Earth Planet. Sci. Lett., 443, 90107. doi:10.1016/j.epsl.2016.02.040.

Costa, A., R. S. J. Sparks, G. Macedonio and O. Melnik (2009). Effects of wall-rock elasticity on magma flow in dykes during explosive eruptions, Earth Planet. Sci. Lett., 288, 455-462. doi:10.1016/j.epsl.2009.10.006.

Costa, A., O. Melnik and E. Vedeneeva (2007a) Thermal effects during magma ascent in conduits, J. Geophys. Res., 112 B12205. doi:10.1029/2007JB004985

Costa, A., O. Melnik and R. S. J. Sparks (2007b). Controls of conduit geometry and wallrock elasticity on lava dome eruptions, Earth Planet. Sci. Lett., 260, 137-151, doi:10.1016/j.epsl.2007.05.024.

De Angelis S., O. D. Lamb, A. Rietbrock, A. Lamur, A. J. Hornby, F. W. von Aulock, Y. Lavallée (2016). Characterization of ash-and-gas explosions at Santiaguito volcano, Guatemala, from infrasound waveform inversion and thermal infrared measurements, Geophys. Res. Lett., 43, 6220-6227. 
doi:10.1002/2016GL069098

de' Michieli Vitturi, M., A. B. Clarke, A. Neri and B. Voight (2008). Effects of conduit geometry on magma ascent dynamics in dome-forming eruptions, Earth Planet. Sci. Lett., 272, 567-578. doi:10.1016/j.epsl.2008.05.025.

de' Michieli Vitturi, M., A. B. Clarke, A. Neri and B. Voight (2013). Extrusion cycles during dome-building eruptions, Earth Planet. Sci. Lett., 371, 372:3748. doi:10.1016/j.epsl.2013.03.037.

Degruyter, W., A. Burgisser, O. Bachmann and O. Malaspinas (2010a). Synchrotron X-ray microtomography and lattice Boltzmann simulations of gas flow through volcanic pumices, Geosphere, 6, 470481. doi:10.1130/GES00555.1.

Degruyter, W., O. Bachmann and A. Burgisser (2010b). Controls on magma permeability in the volcanic conduit during the climactic phase of the Kos Plateau Tuff eruption (Aegean Arc), Bull. Volcanol., 72, 63-74. doi:10.1007/s00445-009-0302-x.

Degruyter, W., O. Bachmann, A. Burgisser and M. Manga (2012). The effects of outgassing on the transition between effusive and explosive silicic eruptions, Earth Planet. Sci. Lett., 349-350, 161-170. doi:10.1007/ s00445-009-0302-x.

Del Bello, E., J. Taddeucci, M. de’ Michieli Vitturi, P. Scarlato, D. Andronico, S. Scollo, U. Kueppers and T. Ricci (2017). Effect of particle volume fraction on the settling velocity of volcanic ash particles: insights from joint experimental and numerical simulations, Sci. Rep., 7, 39620. doi:10.1038/srep39620.

Dellino, P., M. T. Gudmundsson, G. Larsen, D. Mele, J. A. Stevenson, T. Thordarson and B. Zimanowski (2012). Ash from the Eyjafjallajökull eruption (Iceland): Fragmentation processes and aerodynamic behavior, J. Geophys. Res., 117, B00C04. doi:10.1029/2011JB008726.

Diller, K., A. B. Clarke, B. Voight and A. Neri (2006). Mechanisms of conduit plug formation: Implications for vulcanian explosions, Geophys. Res. Lett., 33. doi:10.1029/2006GL027391.

Dingwell D. B., Y. Lavallée, K.-U. Hess, A. Flaws, J. Marti, A. R. L. Nichols, H. A. Gilg and B. Schillinger (2016). Eruptive shearing in tube pumice: pure and simple, Solid Earth, 7, 1383-1393. doi:10.5194/se-71383-1393.

Dominguez, L., L. Pioli, C. Bonadonna and M. Ripepe (2016). Quantifying unsteadiness and dynamics of pulsatory volcanic activity, Earth Planet. Sci. Lett., 444, 160-168. doi:10.1016/j.epsl.2016.03.048.

Dufek, J. and G. W. Bergantz (2005). Transient two-dimensional dynamics of the upper conduit of a rhy- olitic eruption: A comparison of the closure models for the granular stress. J. Volcanol. Geotherm. Res., 143, 113-132. doi:16/j.jvolgeores.2004.09.013.

Edmonds, M., I. R. Sides, D. A. Swanson, C. Werner, R. S. Martin, T. A. Mather, R. A. Herd, R. L. Jones, M. I. Mead, G. Sawyer, T. J. Roberts, A. J. Sutton and T. Elias (2013). Magma storage, transport and degassing during the 2008-10 summit eruption at Kīlauea Volcano, Hawai, Geoch. Cosmochim. Acta, 123, 284-301. doi:10.1016/j.gca.2013.05.03.

Engwell, S. L., W. P. Aspinall and R. S. J. Sparks (2015). An objective method for the production of isopach maps and implications for the estimation of tephra deposit volumes and their uncertainties, Bull Volcanol., 77, 1-18. doi:10.1007/s00445-015-0942-y.

Engwell, S. L., R. S. J. Sparks and W. P. Aspinall (2013). Quantifying uncertainties in the measurement of tephra fall thickness, J. App. Volcanol., 2, 5. doi:10.1186/2191-5040-2-5.

Eychenne, J. and J. L. Le Pennec (2012). Sigmoidal particle density distribution in a subplinian scoria fall, Bull Volcanol, 74: 2243. doi:10.1007/s00445-0120671-4.

Fee, D. and R. S. Matoza (2013). An overview of volcano infrasound: From Hawaiian to Plinian, local to global, J. Volcanol. Geotherm. Res., 249, 123-139. doi:10.1016/j.jvolgeores.2012.09.002.

Fife, J. L., M. Rappaz, M. Pistone, T. Celcer, G. Mikuljan and M. Stampanoni (2012). Development of a laser-based heating system for in situ synchrotronbased X-ray tomographic microscopy. J. Synchr. Rad. 19 (3), 352-358. doi:10.1107/S0909049512003287.

Flower, V. J. and S. A. Carn (2015). Characterising volcanic cycles at Soufriere Hills Volcano, Montserrat: Time series analysis of multi-parameter satellite data, J. Volcanol. Geotherm. Res., 304, 82-93. doi:016/j.jvolgeores.2015.07.035.

Fornaciai, A., P. Landi and P. Armienti (2009). Dissolution/crystallization kinetics recorded in the 20022003 lavas of Stromboli (Italy), Bull. Volcanol., 71, 631-641. doi:10.1007/s00445-008-0249-3.

Gaudin, D., M. Moroni, J. Taddeucci, P. Scarlato, and L. Shindler (2014a). Pyroclast Tracking Velocimetry: A particle tracking velocimetry-based tool for the study of Strombolian explosive eruptions, J. Geophys. Res., 119, 5369-5383, doi:10.1002/2014JB011095.

Gaudin, D., J. Taddeucci, P. Scarlato, M. Moroni, C. Freda, M. Gaeta and D. M. Palladino (2014b). Pyroclast Tracking Velocimetry illuminates bomb ejection and explosion dynamics at Stromboli (Italy) and Yasur (Vanuatu) volcanoes, J. Geophys. Res., 119, 
5384-5397. doi:10.1002/2014JB011096.

Gaudin, D., J. Taddeucci, B. F. Houghton, T. R. Orr, D. Andronico, E. Del Bello, U. Kueppers, T. Ricci, and P. Scarlato (2016). 3-D high-speed imaging of volcanic bomb trajectory in basaltic explosive eruptions, G3, 17, 4268-4275, doi:10.1002/2016GC006560.

Gauthier, P.-J., O. Sigmarsson, M. Gouhier, B. Haddadi, and S. Moune (2016). Elevated gas flux and trace metal degassing from the 2014-2015 fissure eruption at the Bárðarbunga volcanic system, Iceland, J. Geophys. Res. Solid Earth., 121, 1610-1630, doi:10.1002/2015JB012111.

Giordano, D., J. K. Russell and D. B. Dingwell (2008). Viscosity of magmatic liquids: a model, Earth Planet. Sci. Lett., 271, 123-134. doi:10.1016/j.epsl.2008.03.038.

Giordano D. and Russell J.K. (2016). The heat capacity of hydrous multicomponent natural melts and glasses, in press, Chem. Geol., doi:10.1016/j.chemgeo.2016.08.036.

Gonnermann, H. M. and M. Manga (2007). The fluid mechanism inside a volcano, Annu. Rev. Fluid. Mech., 39, 321-356. doi:10.1146/annurev.fluid.39.050905.110207.

Gudmundsson, M. T., T. Thordarson, A. Höskuldsson, G. Larsen, H. Björnsson, F. J. Prata, B. Oddsson, E. Magnússon, T. Högnadóttir, G. N. Petersen, C. L. Hayward, J. A. Stevenson and I. Jónsdóttir (2012). Ash generation and distribution from the April-May 2010 eruption of Eyjafjallajökull, Iceland, Sci. Rep., 2, 572. doi:10.1038/srep00572.

Gudmundsson, M. T. et al. (2016). Gradual caldera collapse at Baflarbunga volcano, Iceland, regulated by lateral magma outflow, Science, 353, aaf8988 (2016). doi:10.1126/science.aaf8988.

Gurioli L. et al. (2015). MeMoVolc consensual document: a review of cross-disciplinary approaches to characterizing small explosive magmatic eruptions, Bull. Volcanol., 77, 49, doi:10.1007/ s00445-015-0935-x.

Gurioli, L., L. Colo, A. J. Bollasina, A. Harris, A. Whittington and M. Ripepe (2014). Dynamics of Strombolian explosions: Inferences from field and laboratory studies of erupted bombs from Stromboli volcano, J. Geophys. Res. Solid Earth, 119, 319345. doi:10.1002/2013JB010355.

Gurioli, L., A. J. L. Harris, B. F. Houghton, M. Polacci and M. Ripepe (2008). Textural and geophysical characterization of explosive basaltic activity at Villarrica volcano, J. Geophys. Res., 113, B08206. doi:10.1029/2007JB005328.

Harris, A. (2013). Thermal remote sensing of active vol- canoes: a user's manual, Cambridge University Press, Cambridge, 728 p.

Hautmann, S., J. Gottsmann, R. S. Sparks, G. S. Mattioli, I. S. Sacks and M. H. Strutt (2010). Effect of mechanical heterogeneity in arc crust on volcano deformation with application to Soufrière Hills Volcano, Montserrat, West Indies, J. Geophys. Res., 115, B09203. doi:10.1029/2009JB006909.

Heap, M. J., Y. Lavallée, L. Petrakova, P. Baud, T. Reuschlé, N. R. Varley and D. B. Dingwell (2014). Microstructural controls on the physical and mechanical properties of edifice-forming andesites at Volcán de Colima, Mexico, J. Geophys. Res. Solid Earth, 119, 925-2963. doi:10.1002/2013JB010521.

Hess K.-U., B. Cordonnier, Y. Lavallée and D. B. Dingwell (2008). Viscous heating in rhyolite: an in situ experimental determination, Earth Planet. Sci. Lett., 275, 121-126. doi:10.1016/j.epsl.2008.08.014.

Hreinsdóttir, S., F. Sigmundsson, M. J. Roberts, H. Björnsson, R. Grapenthin, P. Arason, Th. Árnadóttir, J. Hólmjárn, H. Geirsson, R. A. Bennett, M. T. Gudmundsson, B. Oddsson, B. G. Ófeigsson, T. Villemin, Th. Jónsson, E. Sturkell, Á. Höskuldsson, G. Larsen, Th. Thordarson, and B. A. Óladóttir (2014). Volcanic plume height correlated with magma pressure change at Grímsvötn Volcano, Iceland, Nature Geoscience, 7, 214-218, doi:10.1038/NGEO2044.

Johnson, J. B. and M. Ripepe (2011). Volcano infrasound: A review, J. Volcanol. Geotherm. Res., 206, 61-69. doi:10.1016/j.jvolgeores.2011.06.006.

Jordan, S. C., T. Dürig, R. A. F. Cas and B. Zimanowski (2014). Processes controlling the shape of ash particles: Results of statistical IPA, J. Volcanol. Geotherm. Res., 288, 19-27. doi:10.1016/j.jvolgeores.2014.09.012.

Kendrick J. E., Y. Lavallée, K.-U. Hess, M. J. Heap, H. E. Gaunt, P. Meredith and D. B. Dingwell (2013). Tracking the porous permeable network during strain-dependent magmatic flow, J. Volcanol. Geotherm. Res., 260, 117-126. doi:10.1016/j.jvolgeores.2013.05.012.

Kendrick J. E., Y. Lavallée, K.-U. Hess, S. de Angelis, A. Ferk., H. E. Gaunt, D. B. Dingwell and R. Leonhardt (2014b). Seismogenic frictional melting in the magmatic column, Solid Earth, 5, 19-208. doi:10.5194/se-5-199-2014.

Kendrick J. E., Y. Lavallée Y., T. Hirose, G. Di Toro, A. J. Hornby, S. De Angelis and D. B. Dingwell (2014a). Volcanic drumbeat seismicity caused by stick-slip motion and magmatic frictional melting, Nat. Geosci., 7, 438-442. doi:10.1038/ngeo2146. 
Kendrick J. E., Y Lavallée, N. R. Varley, F. B. Wadsworth, O. D. Lamb, J. Vasseur (2016). Blowing off steam: Tuffisite formation as a regulator for lava dome eruptions, Frontiers in Earth Science, 4. doi:10.3389/feart.2016.00041.

Kolzenburg S., D. Giordano, C. Cimarelli C. and D. B. Dingwell (2016a). In situ thermal characterization of cooling/crystallizing lavas during rheology measurements and implications for lava flow emplacement, Geoch. Cosmoch. Acta, 195, 244-258. doi:10.1016/j.gca.2016.09.022.

Kolzenburg S., M. Favalli, A. Fornaciai, I. Isola, A. Harris, L. Nannipieri, D. Giordano (2016b). Rapid updating and improvement of airborne LIDAR DEMs through ground based SfM 3D modeling of volcanic features, IEEE Transactions on Geoscience and Remote Sensing, PP(99), 1-13. doi:10.1109/TGRS.2016.2587798.

Koulakov, I. (2013). Studying deep sources of volcanism using multiscale seismic tomography, J. Volcanol. Geotherm. Res., 257, 205-226. doi:10.1016/j.jvolgeores.2013.03.012.

Kozono, T., H. Ueda, T. Shimbori and K. Fukui (2014). Correlation between magma chamber deflation and eruption cloud height during the 2011 Shinmoedake eruptions, Earth Planets and Space, 66, 139. doi:10.1186/s40623-014-0139-1.

Kozono, T. and T. Koyaguchi (2009). Effects of relative motion between gas and liquid on 1-dimensional steady flow in silicic volcanic conduits. 2. Origin of diversity of eruption styles, J. Volcanol. Geotherm. Res., 180, 37-49. doi:10.1016/j.jvolgeores.2008.11.007.

Kueppers, U., B. Scheu, O. Spieler and D. B. Dingwell (2005). Field-based density measurements as a tool to identify pre-eruption dome structure: set-up and first results from Unzen volcano, Japan, J. Volcanol. Geotherm. Res., 141, 65-75. doi:10.1016/j.jvolgeores.2004.09.005.

Kueppers, U., B. Scheu, O. Spieler and D. B. Dingwell (2006). Fragmentation efficiency of explosive volcanic eruptions: an analysis of experimental pyroclasts., J. Volcanol. Geotherm. Res., 153, 125-135. doi.org/10.1016/j.jvolgeores.2005.08.006.

La Spina, G. (2014). Finite volume central schemes for a two-phase compressible model with application to gas-liquid Riemann problems and magma ascent dynamics. PhD Thesis, Department of Mathematics, University of Pisa.

La Spina, A., M. R. Burton, P. Allard, S. Alparone and F. Mure (2015). Open-path FTIR spectroscopy of magma degassing processes during eight lava foun- tains on Mount Etna, Earth Planet. Sci. Lett., 413, 123-134. doi:10.1016/j.epsl.2014.12.038.

Lamb, O. D., S. De Angelis and Y. Lavallée (2015). Using infrasound to constrain volcanic ash plume rise models, J. App. Volcanol., 4, 20. doi:10.1186/s13617015-0038-6.

Lamb, O. D., S. De Angelis, K. Umakoshi, A. J. Hornby, J. E. Kendrick and Y. Lavallée (2015). Cyclic fracturing during spine extrusion at Unzen volcano, Japan, Solid Earth 7, 2109-2149.

Lavallée, Y., K.-U. Hess, B. Cordonnier and D. B. Dingwell (2007). A non-Newtonian rheological law for highly-crystalline dome lavas, Geology 35, 843-846. doi: 10.1130/G23594A.1.

Lavallée, Y., P. G. Meredith, D. B. Dingwell, K-U. Hess, J. Wassermann, B. Cordonnier, A. Gerik and J. H. Kruhl (2008). Seismogenic lavas and explosive eruption forecasting, Nature 453(7194): 507-510. doi:10.1038/nature06980.

Lavallée Y., N. Varley, M. A. Alatorre-Ibargüengoitia, K.U. Hess, U. Kueppers, S. Mueller, D. Richard, B. Scheu, O. Spieler and D. B. Dingwell (2012). Magmatic Architecture of dome-building eruptions at Volcán de Colima, Mexico, Bull. Volcanol., 74, 249260. doi:10.1007/s00445-011-0518-4.

Lavallée Y., P. M. Benson, M. Heap, K.-U. Hess, A. Flaws and D. B. Dingwell (2013). Reconstructing magma failure and the degassing network of dome-building eruptions, Geology, 41, 515-518. doi:10.1130/G33948.1.

Lavallée, Y., D. B. Dingwell, C. Cimarelli, A. J. Hornby, J. B. Johnson, J. E. Kendrick, F. W. von Aulock, F. W. Wadsworth, E. Rhodes, B. M. Kennedy, B. J. Andrews and G. Chigna (2015). Thermal vesiculation during volcanic eruptions, Nature, 528, 544-547. doi:10.1038/nature16153.

Lavallée Y., M. J. Heap, U. Kueppers, J. E. Kendrick and D. B. Dingwell (2017). The fragility of $\mathrm{CO}_{2}$ Volcán de Colima - a material constraint. In Volcán de Colima - Managing the Threat. eds: Varley N.R., Komorowski J.-C., Springer.

Leduc, L., L. Gurioli, A. J. L. Harris, L. Colò and E. Rose-Koga (2015). Dynamics of a gas-dominated strombolian explosion. Bull. Volcanol., 77:8. doi:10.1007/s00445-014-0888-5

Lees, J. M. (2007). Seismic tomography of magmatic systems, J. Volcanol. Geotherm. Res., 167, 37-56. doi:10.1016/j.jvolgeores.2007.06.008.

Lesparre, N., D. Gibert, J. Marteau, J.-C. Komorowski, F. Nicollin and O. Coutant (2012). Density muon radiography of La Soufrière of Guadeloupe volcano: comparison with geological, electrical resistivity 
and gravity data, Geophys. J. Inter., 190, 1008-1019. doi:10.1111/j.1365-246X.2012.05546.x.

Lin, G., F. Amelun and Y. Lavallée (2014). Seismic evidence for a crustal magma reservoir beneath the upper east rift zone of Kilauea volcano, Hawaii, Geology, 42, 187-190. doi:10.1130/G35001.1.

Liu, E. J., K. V. Cashman, A. C. Rust and S. R. Gislason (2015a). The role of bubbles in generating fine ash during hydromagmatic eruptions, Geology, 43(3):239-242. doi:10.1130/G36336.1.

Liu, E. J., K. V. Cashman and A. C. Rust (2015b). Optimising shape analysis to quantify volcanic ash morphology, Geo. Res. J., 8, 14-30. doi: 10.1016/j.grj.2015.09.001.

Llewellin, E. W., E. Del Bello, J. Taddeucci, P. Scarlato and S. J. Lane (2011). The thickness of the falling film of liquid around a Taylor bubble, Proc. R. Soc. A., 2012 468, 1041-1064. doi:10.1098/rspa.2011.0476.

Lloyd, S. A., P. Ruprecht, E. H. Hauri, W. Rose, H. M. Gonnermann and T. Plank (2014). NanoSIMS results from olivine-hosted melt embayments: Magma ascent rate during explosive basaltic eruptions, J. Volcanol. Geoth. Res., 283, 1-18. doi:10.1016/j.jvolgeores.2014.06.002.

Longo, A., P. Papale, M. Vassalli, G. Saccorotti, C. P. Montagna, A. Cassioli, S. Giudice and E. Boschi (2012). Magma convection and mixing dynamics as a source of Ultra-Long-Period oscillations, Bull. Volcanol., 74, 873-880. doi:10.1007/s00445-011-0570-0.

Maccaferri, F., M. Bonafede and E. Rivalta (2010). A numerical model of dyke propagation in layered elastic media, Geophys. J. Int., 180, 1107-1123. doi: 10.1111/j.1365-246X.2009.04495.x.

Maccaferri, F., M. Bonafede and E. Rivalta (2011). A quantitative study of the mechanisms governing dike propagation, dike arrest and sill formation, J. Volcanol. Geotherm. Res., 208, 39-50. doi:10.1016/j.jvolgeores.2011.09.001.

Maccaferri, F., E. Rivalta, D. Keir and V. Acocella (2014). Off-rift volcanism in rift zones determined by crustal unloading, Nat. Geo., 7, 297-300. doi:10.1038/ngeo2110.

Maccaferri, F., V. Acocella and E. Rivalta (2015). How the differential load induced by normal fault scarps controls the distribution of monogenic volcanism, Geophys. Res. Lett., 42, 7507-7512. doi:10.1002/2015GL065638.

Maccaferri, F., E. Rivalta, L. Passarelli and Y. Aoki (2016). On the mechanisms governing dike arrest: Insight from the 2000 Miyakejima dike injection, Earth Planet. Sci. Lett., 434, 64-74. doi:10.1016/j.epsl.2015.11.024.

Macedonio, G., F. Dobran and A. Neri (1994). Erosion processes in volcanic conduits and application to the AD 79 eruption of Vesuvius, Earth Planet. Sci. Lett., 121, 137-152. doi:10.1016/0012-821X(94)90037-X.

Mader, H. M., E. W. Llewellin and S. P. Mueller (2013). The rheology of two-phase magmas: A review and analysis, J. Volcanol. Geotherm. Res., 257, 135-158. doi:10.1016/j.jvolgeores.2013.02.014.

Mangan, M., L. Mastin and T. Sisson (2004). Gas evolution in eruptive conduits: combining insights from high temperature and pressure decompression experiments with steady-state flow modeling, J. Volcanol. Geotherm. Res., 129, 23-36. doi:10.1016/S0377-0273(03)00230-0.

Martel, C. (2012). Eruption Dynamics Inferred from Microlite Crystallization Experiments: Application to Plinian and Dome-forming Eruptions of Mt. Pelée (Martinique, Lesser Antilles), J. Petrol., 53, 699-725. doi:10.1093/petrology/egr076.

Marzocchi, W., L. Sandri and C. Furlan (2005). A quantitative model for volcanic hazard assessment, in Statistic in Volcanology Mader H. M., Coles S. G., Connor C.B., Connor L.J. (Editors), Geol. Soc. London, 1, 31-38. doi:10.1144/IAVCEI001.3.

Mastin, L. G. (2002). Insight into volcanic conduit flow from an open-source numerical model, G3, 3(7), 1037. doi:10.1029/2001GC000192.

Melnik, O. (2000). Dynamics of two-phase flow of high-viscosity gas-saturated magma: large variations of sustained explosive eruption intensity, Bull Volcanol. 62, 153-170. doi:10.1007/s004450000072.

Melnik, O., A. A. Barmin and R. S. J. Sparks (2005). Dynamics of magma flow inside volcanic conduits with bubble overpressure buildup and gas loss through permeable magma, J. Volcanol. Geotherm. Res., 143, 53-68. doi:jvolgeores.2004.09.010.

Melnik, O. and A. Costa (2014). Dual-chamber-conduit models of non-linear dynamics behaviour at Soufrière Hills Volcano, Montserrat, Geological Society, London, Memoirs 39.1, 61-69. doi: 10.1144/M39.3.

Mercier, M., A. Di Muro, N. Métrich, D. Giordano, O. Belhadj and C. W. Mandeville (2010). Spectroscopic analysis (FTIR, Raman) of water in mafic and intermediate glasses and glass inclusions, Geochim. Cosmochim. Acta, 74, 5641-5656. doi:10.1016/j.gca.2010.06.020.

Métrich, N. and P. J. Wallace (2008). Volatile abundances in basaltic magmas and their degassing path stracked by melt inclusions. In Minerals, inclusions and volcanic processes, Rev. Mineral. Geochem., 69, 
363-402. doi:10.2138/rmg.2008.69.10.

Métrich, N., A. Bertagnini and A. Di Muro (2010). Conditions of magma storage, degassing and ascent at Stromboli: new insights into the volcano plumbing system with inferences on the eruptive dynamics, J. Petrol. 51(3),603-626. doi:10.1093/petrology/egp083.

Miwa, T., N. Geshi and H. Shinohara (2013). Temporal variation in volcanic ash texture during a vulcanian eruption at the Sakurajima volcano, Japan, J. Volcanol. Geotherm. Res., 260, 80-89. doi:10.1016/j.jvolgeores.2013.05.010.

Mori, T. and M. Burton (2009). Quantification of the gas mass emitted during single explosions on Stromboli with the SO2 imaging camera, J. Volcanol. Geotherm. Res., 188, 395-400. doi:10.1016/j.jvolgeores. 2009.10.005.

Mueller, S., B. Scheu, O. Spieler and D. B. Dingwell (2008). Permeability control on magma fragmentation, Geology, 36, 399-402. doi:10.1130/ G24605A.1.

Namiki, A. and M. Manga (2008). Transition between fragmentation and permeable outgassing of low viscosity magmas, J. Volcanol. Geotherm. Res., 169, 48-60. doi:10.1016/j.jvolgeores.2007.07.020.

Namiki, A. and T. Kagoshima (2014). Intermittent and efficient outgassing by the upward propagation of film ruptures in a bubbly magma, J. Geophys. Res., 119. doi:10.1002/2013JB010576.

Namiki, A., E. Rivalta, H. Woith and T. R. Walter (2016). Sloshing of a bubbly magma reservoir as a mechanism of triggered eruptions, J. Volcanol. Geotherm. Res., 320, 156-171. doi:10.1016/j.jvolgeores.2016.03.010.

Nguyen, C. T., H. M. Gonnermann and B. F. Houghton (2014). Explosive to effusive transition during the largest volcanic eruption of the 20th century (Novarupta 1912, Alaska), Geology 42(8), 703-6. doi:10.1130/G35593.1.

Okumura, S., M. Nakamura, T. Nakano, K. Uesugi and A. Tsuchiyama (2010). Shear deformation experiments on vesicular rhyolite: Implications for brittle fracturing, degassing, and compaction of magmas in volcanic conduits, J. Geophys. Res., 115. doi:10.1029/2009JB006904.

Okumura, S., M. Nakamura, K. Uesugi, T. Nakano and T. Fujioka (2013). Coupled effect of magma degassing and rheology on silicic volcanism, Earth Planet. Sci. Lett., 362, 163-170. doi:10.1016/j.epsl.2012.11.056.

Oppenheimer, C., P. Kyle, F. Eisele, J. Crawford, G. Huey, D. Tanner, S. Kim, L. Mauldin, D. Blake, A. Beyersdorf, M. Buhr and D. Davis (2010). Atmospheric chemistry of an Antarctic volcanic plume, J. Geophys.
Res.-Atmos., 115. doi:10.1029/2009JD011910.

Pamukcu, A. S., G. A. R. Gualda and A.T. Jr Anderson (2012). Crystallization Stages of the Bishop Tuff Magma Body Recorded in Crystal Textures in Pumice Clasts., J. Petrol., 53, 589-609. doi:10.1093/petrology/egr072.

Parker, A. L., J. Biggs and Z. Lu (2016). Time-scale and mechanism of subsidence at Lassen Volcanic Center, CA, from InSAR, J. Volcanol. Geotherm. Res., 320, 117-127. doi: 10.1016/j.jvolgeores.2016.04.013.

Parmigiani, A., S. Faroughi, C. Huber, O. Bachmann and Y. Su (2016). Bubble accumulation and its role in the evolution of magma reservoirs in the upper crust, Nature, 532(7600), 492-495. doi: 10.1038/nature17401.

Passarelli, L., E. Rivalta, S. Cesca and Y. Aoki (2015). Stress changes, focal mechanisms and earthquake scaling laws for the 2000 dike at Miyakejima (Japan), J. Geophys. Res., 120, 4130-4145. doi:10.1002/2014JB011504.

Pichavant, M., I. Di Carlo, S. G. Rotolo, B. Scaillet, A. Burgisser, N. Le Gall and C. Martel (2013). Generation of $\mathrm{CO}_{2}$-rich melts during basalt magma ascent and degassing, Contrib. Mineral. Petrol., 166, 545-561. doi:10.1007/s00410-013-0890-5.

Pioli, L., C. Bonadonna, B. Azzopardi, J. Phillips and M. Ripepe (2012). Experimental constraints on the outgassing dynamics of basaltic magmas, J. Geophys. Res., 117, B03204. doi 10.1029/2011JB008392.

Pistone, M., L. Caricchi, P. Ulmer, L. Burlini, P. Ardia, E. Reusser, F. Marone, and L. Arbaret (2012). Deformation experiments of bubble- and crystal-bearing magmas: Rheological and microstructural analysis, J. Geophys. Res., 117, B05208. doi:10.1029/2011JB008986.

Polacci, M., D. R. Baker, A. LaRue and L. Mancini (2012). Degassing behaviour of vesiculated basaltic magmas:an example from Ambrym volcano, Vanuatu Arc, J. Volcanol. Geotherm. Res., 233-234, 55-64. doi:10.1016/j.jvolgeores. 2012.04.019.

Polacci, M., C. Bouvet de Maisonneuve, D. Giordano, M. Piochi, L. Mancini, W. Degruyter and O. Bachmann (2014). Permeability measurements of Campi Flegrei pyroclastic products: an example from the Campanian Ignimbrite and Monte Nuovo eruptions, J. Volcanol. Geotherm. Res., 272, 16-22. doi:10.1016/j.jvolgeores.2013.12.002.

Putirka, K. D. and F. J. Tepley (editors) (2008). Minerals, inclusions and volcanic processes. Reviews in Mineralogy and Geochemistry, 69, 674 pp.

Ramos, J. I. (1999). Two-dimensional simulations of magma ascent in volcanic conduits, International Journal for Numerical Methods in Fluids, 29, 765-89: Ripepe, M., C. Bonadonna, A. Folch, D. Delle Donne, 
G. Lacanna, E. Marchetti and A. Höskuldssond (2013). Ash-plume dynamics and eruption source parameters by infrasound and thermal imagery: The 2010 Eyjafjallajökull eruption, Earth Planet. Sci. Lett., 366, 112-121. doi:10.1016/j.epsl.2013.02.005. Rivalta, E., M. Bottinger and T. Dahm (2005). Buoyancydriven fracture ascent: Experiments in layered gelatine. J. Volcanol. Geotherm. Res 144 (1-4): 273285. doi:10.1016/j.jvolgeores.2004.11.030.

Rivalta, E. and P. Segall (2008). Magma compressibility and the missing source for some dike intrusions, Geophys. Res. Lett., 35. doi:10.1029/2007GL032521.

Rivalta, E. (2010). Evidence that coupling to magma chambers controls the volume history and velocity of laterally propagating intrusions, J. Geophys. Res., 115, B07203. doi:10.1029/2009JB006922.

Rivalta, E., K. Pascal, J. C. Phillips and A. Bonaccorso (2013). Explosive expansion of a slowly-decompressed magma analog: evidence for delayed bubble nucleation, G3, 14, 3067-3084. doi:10.1002/ ggge.20183.

Rivalta, E., B. Taisne, A. P. Bunger and R. F. Katz (2015). A review of mechanical models of dike propagation: Schools of thought, results and future directions, Tectonophysics, 638, 1-42. doi:10.1016/j.tecto.2014.10.003.

Robert, G., J. K. Russell and D. Giordano (2008a). Rheology of porous volcanic materials: High-temperature experimentation under controlled water pressure, Chem. Geol., 256, 215-229. doi:10.1016/j.chemgeo.2008.06.028.

Robert, G., J. K. Russell, D. Giordano and C. Romano (2008b). High-T deformation of volcanic materials in the presence of water, Am. Mineral., 93, 74-80. doi:10.2138/am.2008.2665.

Russell J. K. and Giordano D. (2016). Modelling Configurational Entropy of Silicate Melts, in press, Chem. Geol.. doi:10.1016/j.chemgeo.2016.07.019.

Rust, A. C. and K. V. Cashman (2011). Permeability controls on expansion and size distributions of pyroclasts, J. Geophys. Res., 116, B11202. doi:10.1029/2011JB008494.

Scharff, L., M. Hort and A. Gerst (2014). The dynamics of the dome at Santiaguito volcano, Guatemala, $\mathrm{CO}_{2}$ Geophys. J. Inter., 197, 1-17. doi:10.1093/gji/ggu069.

Shea, T., J. F. Larsen, L. Gurioli, J. E. Hammer, B. F. Houghton and R. Cioni (2009). Leucite crystals: surviving witnesses of magmatic processes preceding the 79AD eruption at Vesuvius, Italy, Earth Planet. Sci. Lett., 281, 88-98. doi:10.1016/j.epsl.2009.02.014. Shea, T., B. F. Houghton, L. Gurioli, K. V. Cashman, J. E. Hammer and B. Hobden (2010). Textural investi- gations of vesicles in volcanic rocks: an integrated methodology, J. Volcanol. Geotherm. Res., 190, 271289. doi:10.1016/j.jvolgeores.2009.12.003.

Shea, T., L. Gurioli, B. F. Houghton, K. V. Cashman and R. Cioni (2011). Column collapse and generation of pyroclastic density currents during the A.D.79 eruption of Vesuvius: the role of pyroclast density, Geology, 39, 695-698. doi:10.1130/G32092.1.

Shea, T., E. Hellebrand, L. Gurioli and T. Hugh (2014). Conduit- to localized scale degassing during Plinian eruptions: insights from major element and volatile $(\mathrm{Cl}$ and $\mathrm{H} 2 \mathrm{O})$ analysis within Vesuvius AD79 pumice, J. Petrol., 55, 315-344. doi:10.1093/petrology/ egt069.

Shields, J. K., H. M. Mader, M. Pistone, L. Caricchi, D. Floess and B. Putlitz (2014). Strain-induced outgassing of three-phase magmas during simple shear., J. Geophys. Res., 119, 6936-6957. doi: 10.1002/2014JB011111.

Sigmundsson, F. and 36 others (2015) Segmented lateral dyke growth in a rifting event at Bárðarbunga volcanic system, Iceland, Nature, 517, 191-195. doi:10.1038/nature14111.

Sigmundsson, F., S. Hreinsdotir, A. Hooper, Th. Af nadottir, R. Pedersen, M. J. Roberts, N. Okkarsson, A. Auriac, J. Decriem, P. Einarsson, H. Geirsson, M. Hensch, B. G. Offeigsson, E. Sturkell, H. SveinbjoEnsson and K. L. Feigl (2010). Intrusion triggering of the 2010 Eyjafjallajolull explosive eruption, Nature, 468, 426-430. doi:10.1038/nature09558.

Spina L., C. Cimarelli, B. Scheu, D. Di Genova and D. B. Dingwell (2016a). On the slow decompressive response of volatile- and crystal-bearing magmas: an analogue experimental investigation, Earth Planet. Sci. Lett., 433, 44-53. doi:10.1016/j.epsl.2015.10.029.

Spina L., B. Scheu, C. Cimarelli, A. Arciniega-Ceballos and D. B. Dingwell (2016b). Cyclic degassing at basaltic volcanoes: an experimental investigation, Geochem. Geophys. Geosyst., 17, 4179-4194. doi:10.1002/2016GC006455.

Starostin, A., A. Barmin and O. Melnik (2005). A transient model for explosive and phreatomagmatic eruptions., J. Volcanol. Geoth. Res., 143, 133-151. doi:10.1016/j.jvolgeores.2004.09.014.

Taddeucci, J., P. Scarlato, A. Capponi, E. Del Bello, C. Cimarelli, D. M. Palladino and U. Kueppers (2012). High-speed imaging of Strombolian explosions: The ejection velocity of pyroclasts, Geophys. Res. Lett., 39, L02301. doi:10.1029/2011GL050404.

Taddeucci, J., G. A. Valentine, I. Sonder, J. D. L. White, P.-S. Ross, and P. Scarlato (2013). The effect of preexisting craters on the initial development of explo- 
sive volcanic eruptions: An experimental investigation, Geophys. Res. Lett., 40, 507-510. doi:10.1002/grl.50176.

Taddeucci, J., M. A. Alatorre-Ibarguengoitia, D. M. Palladino, P. Scarlato and C. Camaldo (2015). Highspeed imaging of Strombolian eruptions: Gas-pyroclast dynamics in initial volcanic jets, Geophys. Res. Lett., 42, 6253-6260. doi:10.1002/2015GL064874.

Tanaka, H. K. M., T. Uchida, M. Tanaka, H. Shinohara and H. Taira (2009). Cosmic-ray muon imaging of magma in a conduit: Degassing process of Satsuma-Iwojima Volcano, Japan, Geophys. Res. Lett., 36, 1-5. doi:10.1029/2008GL036451.

Tarasewicz, J., B. Brandsdóttir, R. S. White, M. Hensch and B. Thorbjarnardóttir (2012). Using microearthquakes to track repeated magma intrusions beneath the Eyjafjallajökull stratovolcano, Iceland, J. Geophys. Res., 117, B00C06. doi:10.1029/2011JB008751.

Tioukov, V., G. De Lellis, P. Strolin, L. Consiglio, A. Sheshukov, M. Orazi, R. Peluso, C. Bozza,

C. De Sio, M. S. Stellacci, M. Sirignano, N. D'Ambrosio, S. Miyamoto, R. Nishiyama and H. K. M. Tanaka (2017). Muography with nuclear emulsions - Stromboli and other projects, Annals of Geophysics, 60, S0111. doi:10.4401/ag-7386.

Toramaru, A. (2006). BND (bubble number density) decompression rate meter for explosive volcanic eruptions, J. Volcanol. Geotherm. Res., 154, 303-316. doi:10.1016/j.jvolgeores.2006.03.027.

Truby, J. M., S. P. Mueller, E. W. Llewellin and H. M. Mader (2014). The rheology of three-phase suspensions at low bubble capillary number, Proceedings of the Royal Society A, Art. No. 20140557. doi:10.1098/rspa.2014.0557.

Tuffen, H., M. R. James, J. M. Castro and C. I. Schipper (2013). Exceptional mobility of an advancing rhyolitic obsidian flow at Cordón Caulle volcano in Chile, Nat. Comm., 4, 2709. doi:10.1038/ncomms3709.

Valade, S. A., A. Harris and M. Cerminara (2014). Plume Ascent Tracker: Interactive Matlab software for analysis of ascending plumes in image data, Computers \& Geosciences, 66, 132-144. doi:10.1016/j.cageo.2013.12.015.

Valentine, G. A., J. D. L. White, P.-S. Ross, J. Amin, J. Taddeucci, I. Sonder and P. J. Johnson (2012). Experimental craters formed by single and multiple buried explosions and implications for volcanic craters with emphasis on maars, Geophys. Res. Lett., 39, L20301. doi:10.1029/2012GL053716.

Vernon, I., M. Goldstein and R. G. Bower (2010). Galaxy formation: a Bayesian uncertainty analysis,
Bayesian Anal., 5, 619-669. doi:10.1214/10-BA524. Voight, B., R. S. J. Sparks, A. D. Miller, R. C. Stewart, R. P. Hoblitt, A. Clarke, J. Ewart, W. P. Aspinall, B. Baptie, E. S. Calder, P. Cole, T. H. Druitt, C. Hartford, R. A. Herd, P. Jackson, A. M. Lejeune, A. B. Lockhart, S. C. Loughlin, R. Luckett, L. Lynch, G. E. Norton, R. Robertson, I. M. Watson, R. Watts and S. R. Young (1999). Magma flow instability and cyclic activity at Soufriere Hills Volcano, Montserrat, British West Indies, Science, 283, 1138-1142. doi:10.1126/science.283.5405.1138.

von der Lieth, J. and M. Hort (2016). Slug ascent and associated stresses during strombolian activity with non-Newtonian rheology, J. Geophys. Res., 121(7), 4923-42. doi:10.1002/2015JB012683.

Vona, A. and C. Romano (2013). The effects of undercooling and deformation rates on the crystallization kinetics of Stromboli and Etna basalts, Contrib. Mineral. Petrol., 166, 491-509. doi:10.1007/s00410013-0887-0.

Vulpiani, G., M. Ripepe and S. Valade (2016). Mass discharge rate retrieval combining weather radar and thermal camera observations, J. Geophys. Res. Solid Earth, 121, 5679-5695. doi:10.1002/2016JB013191.

Wadsworth F. B., J. Vasseur, F. W. von Aulock, K.-U. Hess, B. Scheu, Y. Lavallée and D. B. Dingwell (2014). Non-isothermal viscous sintering of volcanic ash, J. Geophys. Res. Solid Earth, 119, 8792-8804. doi:10.1002/2014JB011453.

White, J. D. L. and B. F. Houghton (2006). Primary volcaniclastic rocks, Geology, 34, 677-680. doi:10.1130/G22346.1.

Wright, H. M. N., K. V. Cashman, M. Rosi and R. Cioni (2007). Breadcrust bombs as indicators of Vulcanian eruption dynamics at Guagua Pichincha volcano, Ecuador, Bull. Volcanol., 69, 281-300. doi:10.1007/s00445-006-0073-6.

Wright, H. M. N., K. V. Cashman, E. Gottesfeld and J. J. Roberts (2009). Pore structure of volcanic clasts: measurements of permeability and electrical conductivity, Earth Planet. Sci. Lett., 280, 93-104. doi:10.1016/j.epsl.2009.01.023.

Wright, H. M. N. and R. Weinberg (2009). Strain localization in vesicular magma: implications for rheology and fragmentation, Geology, 37, 1023-1026. doi:10.1130/G30199A.1.

Wright, T. J., F. Sigmundsson, C. Pagli, M. Belachew, I. J. Hamling, B. Brandsdóttir, D. Keir, R. Pedersen, A. Ayele, C. Ebinger, P. Einarsson, E. Lewi and E. Calais (2012a). Geophysical constraints on the dynamics of spreading centres from rifting episodes on land, Nat. Geo., 5, 242-250. doi:10.1038/ngeo1428. 
Wright, H. M. N., K. V. Cashman, P. A. Mothes, M. L. Hall, A. G. Ruiz and J-L. Le Pennec (2012b). Estimating rates of decompression from textures of erupted ash particles produced by 1999-2006 eruptions of Tungurahua Volcano, Ecuador, Geology, 40, 619-622. doi:10.1130/ G32948.

Zuccarello, L., M. R. Burton, G. Saccorotti, C. J. Bean and $\mathrm{D}$. Patanè (2013). The coupling between very long period seismic events, volcanic tremor, and degassing rates at Mount Etna volcano, J. Geophys. Res., 18, 4910-4921. doi:10.1002/jgrb.50363.

*Corresponding author: Margherita Polacci,

School of Earth and Environmental Sciences, University of Manchester, Manchester, UK;

email: margherita.polacci@manchester.ac.uk.

(C) 2017 by the Istituto Nazionale di Geofisica e Vulcanologia. All rights reserved. 